Western New England University School of Law

Digital Commons @ Western New England University School of

Law

Faculty Scholarship

Faculty Publications

2019

\title{
The Future of Disability Rights Protections for Transgender People
}

Kevin M. Barry

Quinnipiac University School of Law, kevin.barry@quinnipiac.edu

Jennifer Levi

Western New England University School of Law, jlevi@law.wne.edu

Follow this and additional works at: https://digitalcommons.law.wne.edu/facschol

Part of the Disability Law Commons, and the Law and Gender Commons

\section{Recommended Citation}

Kevin M. Barry \& Jennifer L. Levi, The Future of Disability Rights Protections for Transgender People, 35 TOURO L. REV. 25 (2019).

This Article is brought to you for free and open access by the Faculty Publications at Digital Commons @ Western New England University School of Law. It has been accepted for inclusion in Faculty Scholarship by an authorized administrator of Digital Commons @ Western New England University School of Law. For more information, please contact pnewcombe@law.wne.edu. 


\title{
SYMPOSIUM: CONTEMPORARY ISSUES IN DISABILITY RIGHTS LAW
}

\section{The Future OF Disability RightS Protections for Transgender People}

\author{
Kevin M. Barry \& Jennifer L. Levi*
}

The Americans with Disabilities Act and its predecessor, Section 504 of the Rehabilitation Act of 1973 ("Section 504"), protect people from discrimination based on disability, but not if that disability happens to be one of three archaic medical conditions associated with transgender people: "transvestism," "transsexualism," and "gender identity disorders not resulting from physical impairments." "This Article tells the story of how this transgender exclusion came to be, why a growing number of federal courts say it does not apply to gender dysphoria, a new and distinct medical diagnosis, and the future of disability rights protections for transgender people.

\footnotetext{
* Kevin M. Barry, Professor of Law, Quinnipiac University School of Law \& Jennifer L. Levi, Professor of Law, Western New England University School of Law. This Article is the third in a series of articles tracing the development of disability rights protection for gender dysphoria. For further information on this topic, see the following articles by the authors: Kevin M. Barry et al., A Bare Desire to Harm: Transgender People and the Equal Protection Clause, 57 B.C. L. REv. 507 (2016), and Kevin Barry \& Jennifer Levi, Blatt v. Cabela's Retail, Inc. and a New Path for Transgender Rights, 127 YALE L.J.F. 373 (2017). For other foundational articles on this topic, see Christine Michelle Duffy, The Americans with Disabilities Act of 1990 and the Rehabilitation Act of 1973, in GENDER IDENTITY AND SEXUAL Orientation Discrimination in the WorkPlace: A Practical Guide ch. 16 (2014); Jennifer L. Levi \& Bennett H. Klein, Pursuing Protection for Transgender People Through Disability Laws, in TRANSGENDER Rights 74-92 (Paisley Currah et al. eds., 2006); Kevin M. Barry, Disabilityqueer: Federal Disability Rights Protection for Transgender People, 16 Yale Hum. RTs. \& Dev. L.J. 1 (2013); Jennifer L. Levi, Clothes Don't Make the Man (or Woman), but Gender Identity Might, 15 Colum. J. Gender \& L. 90 (2006). Thanks to participants at the SEALS 2018 Conference Workshop on Labor and Employment Law for helpful conversations; to Michael Morales and Touro Law Review staff for editorial assistance; and to Tina DeLucia, Carmel Joseph, and Jeff Kaplan for research assistance.

142 U.S.C. $§ 12211(b)(1)$ (2018); 29 U.S.C. § 705(20)(F) (2018).
} 
Part I sketches the "matrix" of discrimination that the ADA and Section 504 were intended to redress: prejudice, stereotypes, and societal neglect. Part II briefly discusses the discrimination that people with gender dysphoria - a quintessentially stigmatizing conditionroutinely experience. Part III traces the history of the transgender exclusion, from its inception three decades ago to its recent decline in the district courts. Part IV collects every reported case to have alleged gender dysphoria discrimination under the ADA and Section 504 since 2015 - ranging from employment discrimination to prisoners' rights to access to insurance and identity documents - and discusses the potential impact of these cases in redressing the prejudice, stereotypes, and societal neglect experienced by people with gender dysphoria. Part V offers some concluding remarks.

\section{A DISABILITY DISCRIMINATION MATRIX}

Throughout much of American history, people with disabilities have experienced systemic discrimination, namely prejudice (animusbased attitudes), stereotypes (overbroad generalizations), and neglect (historical exclusion). ${ }^{2}$ They have been hated, stereotyped, and ignored. Such discrimination is especially pronounced for those whose medical conditions are stigmatized - those who have been typed as "abnormal or defective in mind or body" because they "differ too much from a socially defined "norm."”

For many years, government policy toward people with disabilities did not address discrimination; instead, it focused almost exclusively on vocational rehabilitation designed to help people with disabilities overcome their limitations, and on benefits entitlement

2 See Samuel R. Bagenstos, Subordination, Stigma, and “Disability”, 86 VA. L. Rev. 397, 422-26 (2000); see also ADA Amendments Act of 2008, Pub. L. No. 110-325, § 2(a)(2), 122 Stat. 3553 (2008) (codified at 42 U.S.C. $\S \S 12101-12113$ ) (“'II]n enacting the ADA, Congress recognized that ... people with physical or mental disabilities are frequently precluded from [fully participating in all aspects of society] because of prejudice, antiquated attitudes, or the failure to remove societal and institutional barriers.").

3 See Bagenstos, supra note 2, at 437 ("[P] 'norm' are likely to experience all [three types of discrimination]"-i.e., prejudice, stereotypes, and neglect); see also Carol J. Gill, Questioning Continuum, in THE RAGgeD Edge: The Disability Experience from the Pages of the First Fifteen Years of the DisABILITY RAG 42, 44 (Barrett Shaw ed., 1994) ("[D]isability is a marginalized status that society assigns to people who are different enough from majority cultural standards to be judged abnormal or defective in mind or body."). 
programs. ${ }^{4}$ Beginning in the 1970 's, government policy toward people with disabilities radically changed with the emergence of the disability rights movement, which reframed disability as primarily a social condition. 5 According to the "social model" of disability, people are "disabled" not by the functional limitations imposed by their medical conditions, but rather by society's discriminatory reactionsprejudice, stereotypes, and neglect-toward those conditions. ${ }^{6}$ Barriers to full participation for people with disabilities, the model holds, lay not with the individual, but rather with society's unfair treatment of the individual. ${ }^{7}$

As depicted in the diagram below, the ADA and its predecessor, Section 504, embody this understanding. They prohibit policies and practices that "disable" - that perpetuate prejudice, stereotypes, and neglect based on medical conditions. ${ }^{8}$

\footnotetext{
4 See Jennifer L. Levi \& Bennett H. Klein, Pursuing Protection for Transgender People Through Disability Laws, in TRANSGENDER RIGHTS 78 (Paisley Currah et al. eds., 2006); see also Chai R. Feldblum, Definition of Disability Under Federal Anti-Discrimination Law: What Happened?-Why? - And What Can We Do About It?, 21 Berkeley J. EMP. \& LAB. L. 91, 96 (2000) (stating that rehabilitation laws "presumed . . . that integration required changing the person with the disability, not changing any aspect of the surrounding society that might have made it difficult for the person to function in that society").

5 See Bagenstos, supra note 2, at 427-30.

6 See Mary Crossley, Disability Kaleidoscope, 74 Notre Dame L. Rev. 621, 654 (1999) ("[T]he disadvantaged status of persons with disabilities is the product of a hostile (or at least inhospitable) social environment, not simply the product of bodily defects."); see also H.R. REP. No. 101-485(II), at 41 (1990) (House Committee on Education \& Labor) ("The social consequences that have attached to being disabled often bear no relationship to the physical or mental limitations imposed by the disability. For example, being paralyzed has meant far more than being unable to walk - it has meant being excluded from public schools, being denied employment opportunities, and being deemed an 'unfit parent."' (quoting testimony of Arlene Mayerson of the Disability Rights Education and Defense Fund)).

7 See Kevin Barry, Towards Universalism: What the ADA Amendments Act of 2008 Can and Can't Do for Disability Rights, 31 Berkeley J. EMP. \& LAB. L. 203, 212 (2010) ("Under the social model, then, disability is not a problem with the individual - it is a problem with our response to the individual.").

8 Although it is useful for analytical purposes to think of these three types of discrimination as being distinct from each other, there is, of course, much overlap among them. Stereotypes, for example, may be fueled by animus, not ignorance or indifference; and neglect may be driven by overbroad generalizations about the capacities of certain people.
} 


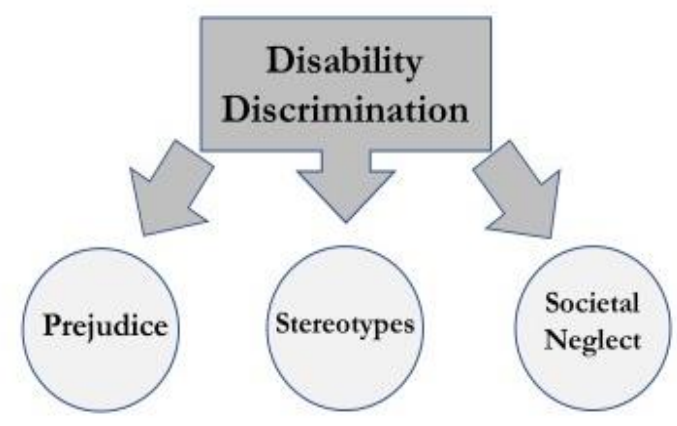

The ADA's text and legislative history confirm this protection from prejudice, stereotypes, and neglect, as do Supreme Court decisions interpreting the ADA and Section 504. ${ }^{9}$

\section{A. Prejudice}

First consider prejudice. The ADA's antidiscrimination provisions expressly target animus-based conduct by prohibiting disparate treatment-intentionally discriminatory actions-such as categorical exclusion or segregation of people with particular medical conditions. $^{10}$ The ADA's findings acknowledge the persistent and pervasive history of "unfair . . . prejudice" against people with disabilities, ${ }^{11}$ as does the ADA's legislative history, which is replete with appalling instances of such prejudice. Examples include a New Jersey zoo keeper who refused to admit children with Down's Syndrome because he feared they would upset the chimpanzees, operators of an auction house who attempted to remove a woman with polio because she was deemed to be "disgusting to look at," a woman with arthritis who was denied a job at a college because the college trustees believed that "normal students shouldn't see her," and a child with cerebral palsy who was excluded from public school because his

9 Given Section 504's lack of legislative history, see, e.g., Alexander v. Choate, 469 U.S. 287, 295 n.13 (1985) (noting lack of congressional debate devoted to Section 504), and its nearly identical language to the ADA, see, e.g., 42 U.S.C. § 12201(a) (requiring the ADA to be construed consistently with Section 504), this Essay's discussion of legislative history and text focuses on the ADA, not Section 504.

10 See, e.g., 42 U.S.C. $\S 12112(\mathrm{~b})(1)-(2)$, (b)(4) (2018) (Title I); id. § 12182(b)(1)(A)-(C) (Title III); 28 C.F.R. $\$ 35.130$ (b)(1)-(2), (d) (2018) (DOJ regulations implementing Title II).

1142 U.S.C. \& 12101(5)-(6), (8) (finding that people with disabilities experience "prejudice," "outright intentional exclusion," and "segregation," and "occupy an inferior status"); see also ADA Amendments Act of 2008 , Pub. L. No. 110-325, § 2(a)(2), 122 Stat. 3553 (2008) (codified at 42 U.S.C. $\S \S 12101-12113$ ) (discussing "prejudice" against people with physical and mental disabilities). 
teacher claimed that his physical appearance "produced a nauseating effect" on his classmates. ${ }^{12}$

Supreme Court case law underscores the ADA's and Section 504's protection of people who have experienced prejudice based on a medical condition. In Alexander v. Choate, the Court located the roots of Section 504, in part, in the "well-catalogued instances of invidious discrimination" against people with disabilities. ${ }^{13}$ And in his concurring opinion several years earlier in City of Cleburne v. Cleburne Living Center, a case in which the Court invalidated a zoning ordinance that discriminated against people with intellectual disabilities in violation of equal protection, Justice Thurgood Marshall vividly recounted this history of prejudice. ${ }^{14}$ People with intellectual disabilities, he explained, "have been subject to a 'lengthy and tragic history' ... of segregation and discrimination that can only be called grotesque" - a "regime of state-mandated segregation and degradation ... that in its virulence and bigotry rivaled, and indeed paralleled, the worst excesses of Jim Crow." 15 Widely considered to be a "menace to society and civilization," people with intellectual disabilities were housed in "[m]assive custodial institutions" designed to "halt [their] reproduction" and "extinguish their race."

\section{B. Stereotypes}

Beyond prejudice, the ADA targets conduct based on stereotypical assumptions. The ADA's antidiscrimination provisions

12 Robert L. Burgdorf Jr., The Americans with Disabilities Act: Analysis and Implications of a Second-Generation Civil Rights Statute, 26 HaRv. C.R.-C.L. L. REv. 413, 418-19 (1991).

13469 U.S. 287, 295 n.12 (1985).

14 See 473 U.S. 432, 435 (1985) (Marshall, J., concurring).

15 Id. at 461-62 (Marshall, J., concurring) (citation omitted).

$16 I d$. at 462. Because Cleburne's facts centered on people with intellectual disabilities, Justice Marshall's stirring portrait of discrimination did not include other forms of statesanctioned discrimination against people with disabilities, including the institutionalization of people with a range of conditions other than intellectual disabilities, such as epilepsy and blindness; the passage of state "ugly laws" that prohibited "unsightly" people-including people with disabilities - from appearing in public; and a built environment that excluded people with disabilities, quite literally, at every step-from the sidewalks encircling their homes to the stairs leading up to the U.S. Capitol. See Bagenstos, supra note 2, at 440-41; see also NAT'L Council on Disability, Equality of Opportunity: The Making of the AMERICANS WITH DiSABILITIES ACT 113 (1997), https://ncd.gov/publications/2010/equality_of _Opportunity_The_Making_of_the_Americans_with_Disabilities_Act [hereinafter EQUALITY OF OPPORTUNITY] (describing Capitol steps as "a symbol of discrimination against the disabled" (quoting Michael Auberger, co-founder of ADAPT)). 
prohibit overbroad rules and qualification standards that have a disparate impact—a "discriminatory effect"-on people with medical conditions, screening them out from opportunities enjoyed by those without a medical condition. ${ }^{17}$ The ADA's findings recognize the pernicious role that "overprotective rules and policies," "exclusionary qualification standards and criteria," and "antiquated attitudes" have had in denying people with medical conditions equal opportunity. ${ }^{18}$ And the ADA's legislative history contains numerous examples of disgraceful actions taken against people with disabilities based on "false presumptions, generalizations, misperceptions, patronizing attitudes, ignorance, irrational fears, and pernicious mythologies,"19 including: a man with AIDS who was forced by police to remain in his car overnight as neighbors peered at him through the car's windows; a woman who was fired from a job she had held for many years because her son, who lived with her, had contracted AIDS; people with epilepsy who were believed to be possessed by the devil and shut out of schools and the workforce; a woman with HIV whose use of a community swimming pool led the town to close the pool for a week and prompted a neighbor to start a petition demanding that she move out of the town; and fully-registered people with disabilities who were turned away

17 See, e.g., 42 U.S.C. $\S 12112(\mathrm{~b})(3)$, (b)(6) (2018) (Title I); id. $\S 12182(\mathrm{~b})(1)(\mathrm{D})$, (b)(2)(A)(i) (Title III); 28 C.F.R. $\$ 35.130(\mathrm{~b})(3)$, (b)(8) (2018) (DOJ regulations implementing Title II).

1842 U.S.C. $\$ 12101(5)$; ADA Amendments Act of 2008, Pub. L. No. 110-325, § 2(a)(2), 122 Stat. 3553 (2008) (codified at 42 U.S.C. $\S \S 12101-12113$ ); see also Americans with Disabilities Act of 1990, Pub. L. No. 101-336, § 2(a)(7) (1990) (finding that people with disabilities have been subjected to discrimination based, in part, on "stereotypic assumptions ... not truly indicative of the individual ability of such individuals to participate in and contribute to society") (removed from ADA by 2008 amendments).

19 H.R. REP. No. 101-485(II), at 30 (1990); see also id. at 40 (discussing "stereotypical assumptions, fears and myths [about people with disabilities] not truly indicative of the ability of such individuals to participate in and contribute to society"); accord S. REP. No. 101-116, at 6 (1989), https://transition.fcc.gov/Bureaus/OSEC/library/legislative_histories/1387.pdf (Senate Committee of Labor and Human Resources). According to Senator Tom Harkin:

There is a wellspring of fears and unfounded prejudices about people with disabilities, unfounded fears, whether people have mental disorders, whether they are manic depressives or schizophrenia or paranoia, or unfounded fears and prejudices based upon physical disabilities. The point of the [ADA] is to start breaking down those barriers of fear and prejudice and unfounded fears, to get past that point so that people begin to look at people based on their abilities, not first looking at their disability.

135 Cong. ReC. S10765-01, S10768, 1989 WL 183216 (Sept. 6, 1989) (statement of Sen. Harkin). 
from voting booths because they did not look sufficiently "competent" to vote. ${ }^{20}$

Numerous Supreme Court decisions support the ADA's and Section 504's mandate to address harmful stereotypes. In 1987, in School Board of Nassau County v. Arline, ${ }^{21}$ the Supreme Court concluded that Section 504 protected a school teacher with tuberculosis who was discharged from her job because of others' fears that she might be contagious. "22 "[T] he basic purpose of $\S 504$," the Court concluded, "is to ensure that handicapped individuals are not denied jobs or other benefits because of the prejudiced attitudes or the ignorance of others"-including "society's accumulated myths and fears about disability and disease." "23 "[D]iscrimination on the basis of mythology," the Court explained, "[is] precisely the type of injury Congress sought to prevent." ${ }^{24}$ Negative stereotypical reactions, themselves, disable.

Arline's observations concerning society's "accumulated myths and fears" about disability also find expression in Justice Thurgood Marshall's concurrence in City of Cleburne v. Cleburne Living Center. According to Justice Marshall, people with intellectual disabilities were "categorically excluded from public schools, based on the false stereotype that all were ineducable and on the purported need to protect [non-disabled] children from them."25 State laws deemed them unfit for citizenship, disqualified them from voting, compelled their sterilization to stop them from procreating, and made their marriages voidable and even criminal. ${ }^{26}$ Although much has changed for people with intellectual disabilities, Justice Marshall explained, this long history of "social and cultural isolation" has resulted in "ignorance, irrational fears, and stereotyping" that continue to endure-"stymie[ing] recognition of the[ir] dignity and individuality." 27

\footnotetext{
20 See H.R. ReP. No. 101-485(II), at 56-57; 136 CONG. REC. S7422-03, S7444, 1990 WL 144937 (June 6, 1990) (statement of Sen. Harkin); EQUALITY OF OPPORTUNITY, supra note 16; accord S. REP. NO. 101-116, at 5-7.

21480 U.S. 273 (1987).

22 Id. at 281.

23 Id. at 284; see also id. at 283 (stating that the ADA covers those who experience "negative reactions ... to the impairment").

$24 I d$. at 285.

25 City of Cleburne v. Cleburne Living Ctr., 473 U.S. 432, $462-63$ (1985).

26 Id. at 463-64.

27 Id. at $464,467$.
} 
Subsequent Supreme Court decisions confirm the law's protection of people with medical conditions from harmful stereotypes. In Bragdon v. Abbott, ${ }^{28}$ the Court held that the ADA's definition of "disability" covered a woman with HIV whose dentist refused to render services out of fear of infection - a position shared by the Department of Justice ("DOJ") and every other agency and court that had considered the issue under Section $504 .^{29}$ In Olmstead v. L.C. ex rel. Zimring, ${ }^{30}$ the Court held that unnecessary institutionalization of people with various mental impairments violated the ADA, in part, because it "stigmatiz[ed]" them, "perpetuat[ing] unwarranted assumptions that persons so isolated are incapable or unworthy of participating in community life." ${ }^{31}$ And in Board of Trustees of the University of Alabama v. Garrett, ${ }^{32}$ Justice Kennedy observed that the ADA prohibits actions based not on "malice or hostile animus alone," but also

insensitivity caused by simple want of careful, rational reflection or from some instinctive mechanism to guard against people who appear to be different in some respects from ourselves. Quite apart from any historical documentation, knowledge of our own human instincts teaches that persons who find it difficult to perform routine functions by reason of some mental or physical impairment might at first seem unsettling to us, unless we are guided by the better angels of our nature. ${ }^{33}$

\section{Societal Neglect}

Lastly, the ADA targets the neglect of people with disabilities, whose "[e]xclusion is literally built into our physical and social environment." ${ }^{34}$ Take, for example, buildings inaccessible to people who use wheelchairs, workplaces that do not permit job coaches for people with mental health conditions, and paper money indistinguishable to a person who is blind. Throughout history, these

524 U.S. 624 (1998).

29 Id. at 628-29, 642-45.

30527 U.S. 581 (1999).

31 Id. at 600 (citation omitted).

32531 U.S. 356 (2001).

33 Id. at 374-75 (Kennedy \& O'Connor, JJ., concurring).

34 Bagenstos, supra note 2, at 425. 
"[societal] norms have arisen out of the cumulative set of actions and decisions" taken by members of the majority - "with any disadvantages resulting to other members of society largely ignored and unacknowledged." 35

The ADA's antidiscrimination provisions address society's historical neglect of people with disabilities by requiring universal design and the removal of architectural barriers, ${ }^{36}$ reasonable accommodations in the workplace, ${ }^{37}$ and reasonable modification of policies, practices, and procedures in government and private business. ${ }^{38}$ The ADA's findings likewise acknowledge the "isolat[ion]" and "inferior status" of people with disabilities, their "relegation to lesser services, programs, activities, benefits, jobs, or other opportunities," and society's "failure to make modifications to existing facilities and practices" and to "remove societal and institutional barriers." 39

Societal neglect of people with disabilities also features in the ADA's and Section 504's legislative history, as well as in Supreme Court decisions interpreting these laws. According to one of the ADA's lead sponsors, Senator Tom Harkin, the ADA “offers promise that [people with disabilities] will no longer be shunned and isolated because of the ignorance of others. ${ }^{40}$ Rather, according to President George H.W. Bush, who signed the ADA into law, people with disabilities will have "the opportunity to blend fully and equally into the rich mosaic of the American mainstream." ${ }^{41}$ As the Supreme Court stated in Alexander, Congress viewed discrimination against people with disabilities as "most often the product, not of invidious animus, but rather of thoughtlessness and indifference-of benign neglect,"

35 Chai R. Feldblum, Rectifying the Tilt: Equality Lessons From Religion, Disability, Sexual Orientation, and Transgender, 54 ME. L. REV. 159, 182 (2002); see also id. at 181 ("Admittedly, these decisions were not taken out of malice or hatred for minority members of society.").

36 See 42 U.S.C. $\S \S 12182(\mathrm{~b})(2)(\mathrm{A})(\mathrm{iv})-(\mathrm{v}), 12183$ (2018) (Title III); 28 C.F.R. $\S \S 35.150$, 35.151 (2018) (DOJ regulations implementing Title II).

37 See 42 U.S.C. $\$ 12112$ (b)(5) (Title I).

38 See id. $\S 12182(\mathrm{~b})(2)(\mathrm{A})(\mathrm{ii})-(\mathrm{iii})$ (Title III); 28 C.F.R. $\S 35.130(\mathrm{~b})(7)$ (DOJ regulations implementing Title II).

3942 U.S.C. $\S \S 12101(2)$, (5); ADA Amendments Act of 2008, Pub. L. No. 110-325, § 2(a)(2), 122 Stat. 3553 (2008) (codified at 42 U.S.C. $\S \S 12101-12113$ ).

40136 CONG. REC. S7422-03, S7444, 1990 WL 144937 (June 6, 1990) (statement of Sen. Harkin).

41 Remarks of President George Bush at the Signing of the Americans with Disabilities Act, EEOC, http://www.eeoc.gov/eeoc/history/35th/videos/ada_signing_text.html (last visited Feb. 26, 2018). 
"apathetic attitudes," and "shameful oversight[]." 42 Section 504, the Alexander Court stated, was intended to remedy the "invisibility of [people with disabilities] in America," who were forced "to live among society "shunted aside, hidden, and ignored." 43 Justices Kennedy and Ginsburg have likewise discussed the "indifference" toward people with disabilities and "systematic exclusion" that motivated passage of the ADA. ${ }^{44}$

\section{Discrimination Against People With Gender DYSPHORIA}

Gender dysphoria is a rare but serious medical condition characterized by a marked incongruence between one's assigned sex at birth and one's gender identity, which results in clinically significant distress. ${ }^{45}$ Without treatment, adults with gender dysphoria experience serious psychological debilitation (e.g., anxiety, depression, suicidality and other mental health issues). ${ }^{46}$ Fortunately, gender dysphoria is curable by medically-recommended and supervised gender transition, which alleviates the distress caused by gender dysphoria and allows one to live a life consistent with one's gender identity. The medical care for the condition is individualized and consists of one or more of four components: living consistent with one's gender; hormone therapy to bring a person's body into conformity with their gender identity; surgery to change primary and/or secondary sex characteristics; and psychotherapy. ${ }^{47}$

People with gender dysphoria routinely face discrimination based on their medical condition and the medical services and treatments they use to treat it. Specifically, they are subject to relentless prejudice, in the form of animus-driven exclusion and segregation; stereotypical assumptions, fears, and pernicious myths, in

42 Alexander v. Choate, 469 U.S. 287, 295-96 (1985).

43 Id. at 296 (quoting 117 CONG. REC. 45974 (1971)).

44 Tennessee v. Lane, 541 U.S. 509, 536 (2004) (Ginsburg, J., concurring); Bd. of Trs. v. Garrett, 531 U.S. 356, 375 (2001) (Kennedy, J., concurring).

45 American Psychiatric Association, Diagnostic and Statistical Manual of MENTAL Disorders 452, 454 (5th ed. 2013) [hereinafter DSM-5].

46 See id. at 454-55.

47 World Prof. Ass'n for Transgender Health, Standards of Care for the Health of Transsexual, Transgender, And Gender Nonconforming People 9-10 (7th ed. 2011), https://www.wpath.org/media/cms/Documents/Web\%20Transfer/SOC/Standards\%20of\%20 Care\%20V7\%20-\%202011\%20WPATH.pdf [hereinafter SOC]. 
the form of overbroad rules and qualification standards that screen them out; and neglect, in the form of refusals to modify policies to permit equal participation. Indeed, gender dysphoria is a quintessentially stigmatizing medical condition - one that is subject to pervasive and persistent discrimination because those with the condition are "not considered to be among the 'normals' for whom society, and its institutions, are designed." 48

According to the American Psychiatric Association, gender dysphoria:

is associated with high levels of stigmatization, discrimination, and victimization, leading to negative self-concept, increased rates of mental disorder comorbidity, school dropout, and economic marginalization, including unemployment, with attendant social and mental health risks, especially in individuals from resource-poor family backgrounds. ${ }^{49}$

The internationally accepted Standards of Care for the treatment of gender dysphoria, published by the World Professional Association for Transgender Health ("WPATH"), similarly recognize the risk of "abuse and stigmatization" of people with gender dysphoria. ${ }^{50}$

Gender dysphoria's close association with transgender people - an "historically persecuted and politically powerless" class who "face discrimination, harassment, and violence because of their gender identity"- -likewise contributes to the discrimination faced by people with gender dysphoria. ${ }^{51}$ Take, for example, the experience of Gavin Grimm and Ash Whitaker, both transgender students, who were

48 See Bagenstos, supra note 2, at 437; see also Doe v. Frank, 951 F.2d 320, 324 (11th Cir. 1992) (noting "the social stigma attached" to "transsexuality"); Lie v. Sky Publ'g Corp., 2002 WL 31492397, at *7 (Mass. Super. Ct. Oct. 7, 2002) (denying employer's motion for summary judgment under Massachusetts' ADA-like, three-pronged definition of disability, and stating that "[i]t cannot be gainsaid that transsexuals have a classically stigmatizing condition that sometimes elicits reactions based solely on prejudices, stereotypes, or unfounded fear").

49 DSM-5, supra note 45, at 458.

50 See SOC, supra note 47 , at 21.

51 Whitaker ex rel. Whitaker v. Kenosha Unified Sch. Dist. No. 1 Bd. of Educ., 858 F.3d 1034, 1051 (7th Cir. 2017); Doe 1 v. Trump, 275 F. Supp. 3d 167, 176 (2017); see generally NAT'l Ctr. For Transgender Equality, The Report of the 2015 U.S. TRansgender SURVEY 4 (2016), https://www.transequality.org/sites/default/files/docs/USTS-Full-ReportFINAL.PDF (surveying nearly 28,000 transgender people and concluding that they are disproportionately at risk for discrimination in almost all aspects of life, including employment, housing, education, public accommodations, and access to government services). 
told by their high school principals that they could not use genderappropriate restrooms because it would violate "the dignity and privacy rights of other students" and would create "safety issues and lewdness concerns." 52 Consider also the experience of current and aspiring transgender military service members who were told by the President of the United States that they were no longer welcome in the military because they were a "burden[]" and a "disruption." 53 Or consider state and local laws that once criminalized cross-dressing in public "to prevent crimes in washrooms; and ... to prevent inherently antisocial conduct which is contrary to the accepted norms of our society." 54

Notwithstanding the discrimination routinely experienced by people with gender dysphoria, few litigants with gender dysphoria have claimed the protection of the ADA and Section 504. Part III explains why this is so, and why this is now changing.

\section{The History of The Transgender ExClusion}

The history of the ADA's and Section 504's transgender exclusion begins in the late 1980's with the successful legislative efforts of several conservative senior U.S. senators, who sought to strip legal protections for medical conditions closely associated with transgender people. Approximately twenty-five years later, the pendulum has swung, as transgender litigants with the new and distinct diagnosis of gender dysphoria successfully claim the protection of the ADA and Section 504.

\section{A. The Making of the Transgender Exclusion: 1987- 1990}

The ADA's predecessor, the Rehabilitation Act, originally protected people with transgender-related diagnoses from discrimination, as demonstrated by a pair of federal district court cases from the mid-1980's. In Doe v. United States Postal Service, ${ }^{55}$ the U.S. Postal Service revoked a transgender woman's conditional job offer

52 Bd. of Educ. of the Highland Local Sch. Dist. v. U.S. Dep't of Educ., 208 F. Supp. 3d 850, 874 (S.D. Ohio 2016); accord Whitaker, 858 F.3d at 1052.

53 Doe 1, 275 F. Supp. 3d at 183.

54 City of Chicago v. Wilson, 389 N.E.2d 522, 524 (Ill. 1978); Doe 1 v. McConn, 489 F. Supp. 76, 80 (S.D. Tex. 1980).

55 Civ. A. No. 84-3296, 1985 WL 9446 (D.D.C. June 12, 1985). 
after she disclosed her intent to undergo gender reassignment surgery. ${ }^{56}$ Describing the case as a "sad" one, the United States District Court for the District of Columbia denied the United States Postal Service's motion to dismiss and held that the plaintiff, who had a "medically and psychologically established need for gender reassignment surgery," had stated a claim for disability discrimination under the Rehabilitation Act. ${ }^{57}$

Similarly, in Blackwell v. United States Department of the Treasury, ${ }^{58}$ a Treasury Department supervisor canceled a job vacancy just hours after interviewing the plaintiff, a transgender woman, notwithstanding her priority hiring credentials (she had worked for nearly ten years in other branches of the Treasury Department and had been laid off due to a reduction in force) and the recommendation of an experienced, competent interviewer that the plaintiff be hired. ${ }^{59}$ According to the United States District Court for the District of Columbia, the Treasury Department's actions were "highly reprehensible"; the Department supervisor "knew [the] plaintiff could

$56 \quad I d$. at $* 2-3$.

57 Id. at *1. At the time the Doe v. USPS case was decided, "transsexualism" was used by medical and non-medical communities interchangeably with the diagnosis of GID. Compare American Psychiatric Association, Diagnostic and Statistical Manual of Mental DISORDERS 261-66 (3rd ed. 1980) [hereinafter DSM-3] (using "transsexualism" to refer to the diagnosis of GID in adults and adolescents; children with GID received a diagnosis of "GID of Childhood"), with Christine Michelle Duffy, The Americans with Disabilities Act of 1990 and the Rehabilitation Act of 1973, in GENDER IDENTITY AND SEXUAL ORIENTATION Discrimination in the WorkPlace: A Practical Guide 16-48 (2014) ("It was not uncommon at the time [the ADA was being debated] for people to use the terms 'transsexualism' and 'GID' interchangeably."). Transsexualism was removed from the DSM in 1994 and is no longer identified as a medical condition in the DSM. See AMERICAN Psychiatric Association, Diagnostic and Statistical Manual of Mental Disorders 532-38 (4th ed. 1994) [hereinafter DSM-IV] (combining the diagnoses of "Transsexualism" and "GID of Childhood" into the single diagnosis of "GID in children and in adolescents or adults"). The International Classification of Diseases ("ICD"), published by the World Health Organization, has traced a similar path, originally using "transsexualism" to refer to the diagnosis of GID in adults and adolescents, and later substituting "gender incongruence" for "transsexualism" in the most current edition of the ICD, the ICD-11, published in June 2018. ICD-11 FOR Mortality and Morbidity Statistics, Gender InCONGRUENCE (Dec. 2018), https://icd.who.int/browse1 1/l-m/en\#/http\%3a\%2f\%2fid.who.int $\% 2$ ficd $\% 2$ fentity $\% 2 f 411470$ 068; see Jack Drescher et al., Minding the Body: Situating Gender Identity Diagnoses in the ICD-11, 24 INT'L REV. PSYCHIATRY 568, 568-69 (2012) (providing history of gender identity diagnostic classification). The word "transsexual" is fading out of general use, but it describes a person who has or will undergo gender transition and it has been used interchangeably with the word transgender. See DSM-5, supra note 45, at 451.

58656 F. Supp. 713 (D.D.C. 1986), aff'd in part, vacated in part on other grounds, 830 F.2d 1183 (D.C. Cir. 1987).

59 Id. at 714-15. 
do the job and had no sound basis for even refusing to accept him for the job." ${ }^{\prime 0}$ Following a bench trial, the United States District Court for the District of Columbia concluded that the plaintiff had a medical condition that was protected under the Rehabilitation Act, ${ }^{61}$ but ultimately ruled against the plaintiff because she had not shown that she was refused hire on that basis. ${ }^{62}$

Senator Jesse Helms (R-NC) objected to courts' recognition of transgender-related medical diagnoses as protected disabilities under the Rehabilitation Act on moral grounds. In 1987, during Senate debate on a bill to override President Ronald Reagan's veto of the Civil Rights Restoration Act - which expanded the scope of coverage of the Rehabilitation Act and several other federal antidiscrimination statutes-Helms cited the Blackwell case in an attempt to defeat the override. ${ }^{63}$ According to Helms, civil rights laws should not prohibit

private institutions [that receive federal financial assistance], particularly schools and day care centers, . . . from making employment decisions based on moral qualifications. ... [T] his bill opens the way for private institutions all over the country to find themselves forced to justify exclusion of various behaviorally handicapped persons from benefits by evidence from

$60 I d$. at 715 .

$61 I d$. (using the language of "transvesti[sm]" to refer to the plaintiff). "Transvestite" and "transvestism" are derogatory terms that were often used historically to refer to transgender people. See HR Compl. II 185, Tips for Managing GLBT in the Workplace, 2015 WL 8495422; see generally Dallas Denny, Transgender Communities, in TRANSGENDER RIGHTS 184 (2006) (distinguishing "transgender" from labels such as "transvestite" that were "bestowed by the medical community and are in a sense slave names"). At the time of the Blackwell case, these words were used by non-medical communities interchangeably with "transsexual" and "transsexualism." It is clear from the facts of Blackwell that the plaintiff had undergone gender transition and was transgender. According to the court, in addition to dressing in female attire, the plaintiff "had foam implanted in h[er] breasts, and ha[d] effected other changes in h[er] physical appearance," including "female dress and adornments." Blackwell, 656 F. Supp. at 714.

62 The court held that the plaintiff was fired not because of a transgender-related medical condition, but rather because of her sexual orientation. Id. at 715 (stating that the Department supervisor "found plaintiff's apparent homosexual aspect undesirable and changed the rules to avoid the inevitable administrative hassle that would occur if he declined a qualified applicant who was carrying priority hiring credentials because of the RIF.").

63 See Ruth Colker, Homophobia, AIDS Hysteria, and the Americans with Disabilities Act, 8 J. GENDER, RACE \& JUST. 33, 37-39 (2004) (discussing legislative history of Civil Rights Restoration Act of 1987). 
medical doctors and other experts, but not from morals or theology. ${ }^{64}$

Although Helms lost this argument when Congress passed the Civil Rights Restoration Act of 1987 over the President's veto, he returned to the issue the following year. In 1988, during Senate debate on a bill to amend the Fair Housing Act to prohibit housing discrimination based on disability status, Helms successfully argued for the bill's exclusion of protection of conditions associated with being transgender. ${ }^{65}$ After reciting the facts and holding of the Blackwell case, in which the court recognized Section 504's protection of people with transgender-related medical conditions, Helms quipped that his amendment would "put a little common sense back into the equation." 66 The amendment, which excluded transgender-related medical conditions from both the Fair Housing Act and Section 504, passed overwhelmingly. ${ }^{67}$

Senator Alan Cranston, a principal author of Section 504 of the Rehabilitation Act and one of only two senators to oppose the Helms amendment, rose in objection. ${ }^{68}$ Cranston argued that the Helms amendment was fueled by moral animus against transgender people and was at odds with the purpose of the law. "I see this amendment," he stated,

as a direct attack on the heart and soul of antidiscrimination laws, which protect individuals against discrimination based on stereotypes.

In 1973 when section 504 was enacted, Congress recognized that a great deal of the discrimination facing disabled individuals is not the inevitable result of their handicapping condition, but, rather, arises out of the

64134 Cong. ReC. S2399-02 (Mar. 17, 1988) (statement of Sen. Helms), 1988 WL 1084657.

65 See Fair Housing Amendments Act of 1988, Pub. L. No. 100-430, § 6(b)(3), 102 Stat. 1619, 1622 (1988) (codified as a note to 42 U.S.C. § 3602) (excluding coverage of "transvestites"); see also Kevin M. Barry, Disabilityqueer: Federal Disability Rights Protection or Transgender People, 16 YAle HuM. RTS. \& DeV. J. 1, 15 n.62, 25 n.132 (2013) (discussing legislative history of Fair Housing Amendments Act); Colker, supra note 63, at 39 (same).

66134 Cong. REC. S10,470 (daily ed. Aug. 1, 1988) (statement of Sen. Jesse Helms) (on file with author).

67 Fair Housing Amendments Act of 1988, $\S 6(\mathrm{~b})(3)$ (excluding coverage of "transvestites"); 134 CONG. REC. S10,471 (noting 89-2 Senate vote in favor of amendment).

68134 Cong. REC. S10,470-71 (statement of Sen. Alan Cranston). 
false perceptions and prejudices that others hold about individuals who have those conditions. The clear congressional intent was to sweep broadly - to change attitudinal barriers which had served so unfairly to deprive disabled persons of the rights and opportunities afforded to other Americans.

This amendment would single out one category of individuals who are already being discriminated against and say to them, "Sorry you now have no protections. Congress has decided that it no longer cares whether or not you are cast out of our society." 69

The Helms amendment, Cranston concluded,

could open the door to any number of attempts to exclude other disabilities from this and other antidiscrimination laws. ... [T] he whole purpose of . . . antidiscrimination laws is to provide across-the-board, evenhanded protection, not to pick and choose disabilities we approve of and exclude the ones we don't. $^{70}$

Senator Cranston's insight proved prescient. In 1989, during Senate debate on the ADA, Helms successfully proposed an identical amendment that excluded transgender-related medical conditions from the bill's protections. ${ }^{71}$ William Armstrong, a conservative senator from Colorado, further proposed to exclude a broad list of mental health conditions. ${ }^{72}$ In negotiations over Armstrong's amendment, the list was eventually whittled down to approximately eleven conditions, which included kleptomania, pyromania, and psychoactive substance abuse disorders resulting from illegal drug use; sexual behavior

69 Id.

$70 \mathrm{Id}$.

7142 U.S.C. $\$ 12208$ (2018); 135 ConG. REC. S10,776 (daily ed. Sept. 7, 1989), 1989 WL 183216 (noting passage of amendment no. 716).

72135 Cong. ReC. S10,753-54 (daily ed. Sept. 7, 1989) (statement of Sen. William Armstrong), 1989 WL 183115; see also 135 CONG. REC. S11,175-76 (daily ed. Sept. 14, 1989) (statement of Sen. William Armstrong), 1989 WL 183785 (discussing excluded conditions). 
disorders, such as pedophilia, exhibitionism, and voyeurism; and three conditions associated with transgender people: transvestism, transsexualism, and gender identity disorders. ${ }^{73}$ Armstrong's amendment, co-sponsored by Senator Orrin Hatch, passed the Senate and, with several modifications at conference, became law. ${ }^{74}$ Two years later, Congress passed an identical exclusion to the Rehabilitation Act. ${ }^{75}$

As was the case with the exclusion of transgender-related conditions from Section 504 and the Fair Housing Act, legislative history reveals that the ADA's exclusions were based on the moral opprobrium of several senior senators. Senator Armstrong "could not imagine the [ADA's] sponsors would want to provide a protected legal status" to people with mental health conditions that "might have a moral content to them."76 According to Senator Helms, the ADA exclusions were needed because "moral standards" should allow employers to disfavor certain medical conditions. ${ }^{77}$ And Senator Warren Rudman characterized the excluded conditions as "socially unacceptable behavior" that "lacks any physiological basis. In short, we are talking about behavior that is immoral, improper, or illegal and which individuals are engaging in of their own volition.",78

By contrast, disability and lesbian-gay-bisexual rights activists had deep misgivings about the ADA exclusions, particularly its three transgender-related exclusions. EEOC Commissioner Chai Feldblum, who was a staff attorney with the ACLU AIDS Project at the time, originally resisted negotiating with Armstrong and instead advised the bill's sponsors to put Armstrong's amendment to a vote, which she

73 Barry, supra note 65, at 24 (discussing negotiation of Armstrong's amendment).

7442 U.S.C. § 12211(b)(1); 135 Cong. REC. S10,785 (daily ed. Sept. 7, 1989) (noting passage of amendment no. 722). The House of Representative's version of excluded conditions explicitly characterized the three transgender-related conditions as "sexual behavior disorders," inserted the words "not resulting from physical impairments" after "gender identity disorders," and removed the exclusion of "current psychoactive substanceinduced organic mental disorders." H.R. REP. NO. 101-596, at 88 (1990), reprinted in 1990 U.S.C.C.A.N. 565, 597, 1990 WL 121679. This version of excluded conditions was accepted at conference. Id.

7529 U.S.C. § 705(20)(F) (2018) ; H.R. REP. No. 102-973, at 158 (1992), 1992 WL 322488 (discussing amendment of Rehabilitation Act).

76135 CONG. REC. S10,734 (daily ed. Sept. 7, 1989) (statement of Sen. William Armstrong).

77135 CONG. REC. S10,772 (daily ed. Sept. 7, 1989) (statement of Sen. Jesse Helms).

78135 Cong. REC. S10,796 (daily ed. Sept. 7, 1989) (statement of Sen. Warren Rudman). This debate was eerily similar to the "moral standards" arguments subsequently made during the debate over the passage of DOMA and thereafter rejected as an acceptable basis for legislating by the Supreme Court in United States v. Windsor. 570 U.S. 744, 770-71 (2013). 
predicted would fail handedly. ${ }^{79}$ When Senator Hatch demanded that Feldblum give him "more" conditions to add to the negotiated list, she reluctantly agreed. ${ }^{80}$ Similarly, Peri Jude Radecic, lobbyist for the National Gay and Lesbian Task Force at the time of the ADA's passage, supported the ADA's exclusion of homosexuality and bisexuality, but stated that, "as far as the other categories are concerned, I think that anytime that people are removed from protections, I don't necessarily think that's a good situation. I'm not happy anyone is excluded from the bill." ${ }^{\prime 1}$ And, according to Professor Bob Burgdorf, who drafted the original version of the ADA in 1988 as a staffer for (what was then known as) the National Council on the Handicapped, the ADA exclusions were "wholly inconsistent with the overall tenor of the Americans with Disabilities Act," reflecting those "preconceived assumptions and stereotypes" that the ADA was intended to dismantle. ${ }^{82}$

\section{B. The Transgender Exclusion, the ADA Amendments Act, and the DSM-5: 1990-2014}

In the years following the ADA's passage, several transgender litigants who experienced employment discrimination on the basis of gender identity disorder (GID) and transsexualism sought protection under the ADA and Rehabilitation Act. None were successful. In each case, the district court ruled against the plaintiffs by invoking the transgender-related exclusions with little or no elaboration, and without reference to the constitutional dimensions of the exclusionsincluding the moral animus underlying them. ${ }^{83}$

Although the transgender-related exclusions effectively prevented transgender litigants from challenging disability discrimination under federal law for nearly three decades, disability discrimination challenges under state law have often been successful.

79 Barry, supra note 65, at 23-25 (discussing legislative history of ADA's transgender exclusion).

80 Id. at 24.

81 Katrina C. Rose, Where the Rubber Left the Road: The Use and Misuse of History in the Quest for The Federal Employment Non-Discrimination Act, 18 TEMP. POL. \& C.R. L. REV. 397, 436 n.199 (2009).

82 See Burgdorf Jr., supra note 12, at 452 \& 519; see also id. at 519 ("[I]t is arguable that the members of Congress relied upon nothing other than their own negative reactions, fears and prejudices in fashioning the list of excluded classes.").

83 See Duffy, supra note 57, at 16-45 to 16-48 (discussing cases decided between 1994 and 2004). 
Approximately forty-three states have adopted disability antidiscrimination laws that track the ADA definition of disability virtually verbatim. ${ }^{84}$ Notably, only ten of these states have imported the ADA's transgender exclusion. ${ }^{85}$ In the remaining forty states with no transgender exclusion in their disability antidiscrimination laws, a majority of courts and state agencies that have addressed the issue have held that GID and transsexualism are protected disabilities under state antidiscrimination laws. ${ }^{86}$ In 2001, in Doe ex rel. Doe v. Yunits,${ }^{87}$ for example, the Superior Court of Massachusetts held that a transgender female high school student who was prohibited from wearing genderappropriate clothing to school stated a claim for disability discrimination under the Massachusetts constitution. ${ }^{88}$ Such a result, the court reasoned, reflected the Commonwealth of Massachusetts' "proud and independent tradition in protecting the civil rights of its citizens"-particularly those with "traits that ma[k]e them misunderstood and despised." $" 89$

In 2008, Congress amended the ADA by abrogating a series of U.S. Supreme Court decisions that unduly narrowed the ADA's definition of disability contrary to legislative intent. ${ }^{90}$ Specifically, through its findings, purposes, and revised definitions, the ADAAA rejected: the "demanding standard for qualifying as disabled" erected by the Court in Toyota Motor Manufacturing, Kentucky, Inc. v. Williams; the requirement of the Court in Sutton v. United Airlines, Inc. (and its companion cases) that courts consider the ameliorative effects of medication and other measures in assessing the limitations imposed by a medical condition; and Sutton's narrowing of the ADA's capacious third prong, which covers those "regarded as" having a

84 Kevin M. Barry et al., A Bare Desire to Harm: Transgender People and the Equal Protection Clause, 57 B.C. L. REV. 507, 523 (2016).

85 Id.

86 See Duffy, supra note 57, at 16-111 to 16-124 (comparing favorable judicial and administrative decisions in Connecticut, Illinois, Massachusetts, New Hampshire, New Jersey, New York, and Washington, with adverse decisions in Iowa and Florida); see also id. at 16123 (discussing Pennsylvania Human Relations Commission's January 2011 amicus brief in Stacy v. LSI Corp., which argued that Pennsylvania's antidiscrimination law does not exclude gender identity disorders).

87 No. 00-1060A, 2001 WL 36648072 (Mass. Super. Ct. Feb. 26, 2001).

88 See id. at $* 5$.

89 Id.

90 See ADA Amendments Act of 2008, Pub. L. No. 110-325, 122 Stat. 3553 (2008) (codified at 42 U.S.C. $\$ \S 12101-12113$ ). 
disability. ${ }^{91}$ As clarified by the ADAAA, the ADA requires employers, state and local governments, and private businesses to reasonably accommodate a person with a medical condition that is actually limiting or that would be limiting, absent treatment. ${ }^{92}$ The ADA further prohibits employers, state and local governments, and private businesses from engaging in all other types of discrimination against a person with a real or perceived medical condition, regardless of whether the condition is or would be limiting. ${ }^{93}$ Importantly, because the Supreme Court has never interpreted the ADA's transgender exclusion, the ADAAA did not address the exclusionmuch less remove it.

In 2013, the American Psychiatric Association (APA) published the fifth edition of its authoritative treatise, the Diagnostic and Statistical Manual of Mental Disorders (DSM-5), which replaced the diagnosis of "gender identity disorders" with "gender dysphoria." 94 This replacement was more than semantic, reflecting a substantive difference between the medical conditions themselves.

Unlike the outdated diagnosis of gender identity disorder, which the APA first introduced in the DSM in 1980, the hallmark or presenting feature of gender dysphoria is not a person's gender identity. ${ }^{95}$ Rather, it is the clinically significant distress, termed dysphoria, that people experience as a result of the mismatch between a person's gender identity and their assigned sex. ${ }^{96}$ Reflecting this distinction, the diagnostic criteria for gender dysphoria in the DSM-5 are different than those for gender identity disorder. For example, the criteria for gender dysphoria, unlike gender identity disorder, include a "posttransition specifier for people who are living full-time as the

9142 U.S.C. § 12102(3)(A) (2018) (expanding "regarded as" prong); id. § 12102(4)(B) (citing ADAAA's findings that, in turn, reject "demanding standard"); id. § 12102(4)(E) (determining disability without consideration of ameliorative effects of mitigating measures).

92 See id. $\S 12201(\mathrm{~h})$ (requiring showing of substantial limitation of major life activity in reasonable accommodation cases); id. $\S 12102(4)(\mathrm{E})$ (prohibiting consideration of ameliorative effects of mitigating measures in determining substantial limitation of major life activity).

93 See id. § 12201(h) (requiring no showing of substantial limitation of major life activity in non-reasonable accommodation cases).

94 DSM-5, supra note 45, at 452-53.

95 See DSM-5, supra note 45, at 452-53, 814-15.

96 See American Psychiatric Association, Gender Dysphoria 2 (2013), https://www.psychiatry.org/File\%20Library/Psychiatrists/Practice/DSM/APA_DSM-5-Gend er-Dysphoria.pdf (stating that gender identity disorder connoted "that the patient is 'disordered"'). 
desired gender . . . modeled on the concept of full or partial remission." 97 Thus, there are people with gender dysphoria-namely, gender dysphoria posttransition - that would not meet the criteria for gender identity disorder because their distress associated with having a gender identity not typically associated with their assigned sex has been ameliorated by their having undergone gender transition. ${ }^{98}$ Furthermore, the diagnosis of gender dysphoria in the DSM-5 rests upon a growing body of scientific research showing that gender dysphoria has a physical cause related to the interaction of the developing brain and sex hormones. ${ }^{99}$

\section{Challenging the Transgender Exclusion: 2014-2017}

In 2014, in the case of Blatt v. Cabela's Retail, Inc., ${ }^{100}$ a transgender woman diagnosed with gender dysphoria challenged workplace discrimination under Title VII and the ADA. ${ }^{101}$ When her employer moved to dismiss the ADA claim based on the ADA's transgender exclusion in 2015, Ms. Blatt advanced three distinct theories for why the exclusions violated equal protection. ${ }^{102}$

First, she argued that the exclusions should be subjected to heightened scrutiny because discrimination based on transgender status is a suspect/quasi-suspect classification under the Supreme Court's four-factor test: transgender people have suffered a history of discrimination; transgender status does not affect a person's ability to participate in society; it is a core aspect of a person's identity, unchangeable, and impervious to external influences; and transgender

97 DSM-5, supra note 45, at 814-15.

98 See id.

99 See id. at 457 (discussing possible genetic and physiological underpinnings of gender dysphoria); see also Duffy, supra note 47, at 16-72 to 16-74 \& n.282 (citing numerous medical studies conducted in past eight years that "point in the direction of hormonal and genetic causes for the in utero development of gender dysphoria"); Second Statement of Interest of the United States at 5, Blatt v. Cabela's Retail, Inc., No. 5:14-cv-4822-JFL, 2015 WL 9872493 (E.D. Pa. Nov. 16, 2015) (discussing "the evolving scientific evidence suggesting that gender dysphoria may have a physical basis").

100 No. 5:14-cv-4822-JFL, 2017 WL 2178123 (E.D. Pa. May 18, 2017).

101 See id. at *1-2.

102 See Plaintiff's Memorandum of Law in Opposition to Defendant's Partial Motion to Dismiss Plaintiff's First Amended Complaint, Blatt v. Cabela's Retail, Inc., No. 14-4822, 2015 WL 1360179, at*17-39 (E.D. Pa. Jan. 20, 2015), [hereinafter Blatt Br. in Opp'n]. For further discussion of the constitutional issues at issue in this case, see generally Barry et al., supra note 84 . 
people are a minority lacking political power. ${ }^{103}$ Significantly, Ms. Blatt was among the first to argue that discrimination based on transgender status constitutes a suspect/quasi-suspect classification. ${ }^{104}$ She would not be the last, as demonstrated by recent litigation challenging the Trump administration's ban on transgender service members and cases challenging transgender discrimination by states. $^{105}$ Second, and relatedly, Ms. Blatt argued that the ADA's exclusions should be subjected to heightened scrutiny because transgender discrimination is necessarily sex-based: it reflects sex stereotypes and is also based on a person's change of sex or assigned sex at birth. ${ }^{106}$ Under either theory, Ms. Blatt argued, the exclusions failed heightened scrutiny because there was no compelling or

103 See Blatt Br. in Opp'n, supra note 102, at 18-26; see also Barry et al., supra note 84, at 550-67 (arguing that transgender discrimination is entitled to heightened scrutiny based on Supreme Court's four-factor test).

104 Prior to this time, equal protection challenges to transgender discrimination alleged that such discrimination was based on "sex" and was therefore entitled to intermediate scrutiny. See Barry et al., supra note 84, at 568 (discussing cases holding that transgender discrimination is sex discrimination in violation of equal protection).

105 See, e.g., Doe 1 v. Trump, 275 F. Supp. 3d 167, 208-09 (D.D.C. 2017), vacated by Doe 2 v. Shanahan, No. 18-5257, 2019 WL 102309 (D.C. Cir. Jan. 4, 2019) (concluding that "transgender individuals . . . appear to satisfy the criteria of at least a quasi-suspect classification," and applying "intermediate level of scrutiny" to President Trump's transgender military ban because "discrimination on the basis of someone's transgender identity is a quasisuspect form of classification that triggers heightened scrutiny"); Evancho v. Pine-Richland Sch. Dist., 237 F. Supp. 3d 267, 288 (W.D. Pa. 2017) (concluding that "all of the indicia for the application of the heightened intermediate scrutiny standard are present" for transgender individuals, and applying "an intermediate standard of Equal Protection review" to school policy that prohibited students from using restroom consistent with their gender identity); accord Bd. of Educ. of the Highland Local Sch. Dist. v. U.S. Dep't of Educ., 208 F. Supp. 3d 850, 874 (S.D. Ohio 2016); Adkins v. City of N.Y., 143 F. Supp. 3d 134, 139-40 (S.D.N.Y. 2015); see also Fabian v. Hosp. of Cent. Conn., 172 F. Supp. 3d 509, 524 n.8. (D. Conn. 2016).

106 See Blatt Br. in Opp'n, supra note 102, at 28; see, e.g., Whitaker ex rel. Whitaker v. Kenosha Unified Sch. Dist. No. 1 Bd. of Educ., 858 F.3d 1034, 1051 (7th Cir. 2017) (applying "heightened review" because school district's bathroom policy, which required transgender students to use the bathroom consistent with the sex listed on their birth certificates, was "inherently based upon a sex-classification"); Glenn v. Brumby, 663 F.3d 1312, 1316, 1319 (11th Cir. 2011) (affirming trial court's grant of summary judgment in favor of transgender employee because "discriminating against someone on the basis of his or her gender nonconformity constitutes sex-based discrimination under the Equal Protection Clause" and is therefore "subject to heightened scrutiny"); Smith v. City of Salem, 378 F.3d 566, 577 (6th Cir. 2004) (holding that transgender employee's "claims of gender discrimination . . . easily constitute a claim of sex discrimination grounded in the Equal Protection Clause"); Doe 1, 2017 WL 4873042, at *27-28 (applying "intermediate level of scrutiny" because transgender discrimination is "a form of discrimination on the basis of gender, which is itself subject to intermediate scrutiny"); see also Barry et al., supra note 84, at 567-73 (arguing that transgender discrimination is entitled to heightened scrutiny because it is sex-based). 
important reason to exclude transgender people from the ADA's protections. ${ }^{107}$

Lastly, Ms. Blatt argued that the ADA's transgender exclusion failed even the most deferential level of scrutiny-rational basisbecause it was rooted in moral animus against a disfavored group. ${ }^{108}$ Such a bare desire to harm, she argued, cannot constitute a legitimate governmental interest. ${ }^{109}$

In a detailed legal memorandum sent to Attorney General Eric Holder, six state and national transgender rights organizations urged DOJ to take the position that the ADA's transgender exclusion was unconstitutional. ${ }^{110}$ The Blatt case "presents the right vehicle at the right time to challenge the constitutionality of the [ADA's transgender exclusion]," the memorandum stated. ${ }^{111}$ "A quarter century after [the ADA's] adoption," the memorandum continued, "is long past the time for a court to strike this pernicious exclusion and clear the way for transgender people to enjoy the same protections under the law that other people with profound health conditions, whether stigmatized or not, currently enjoy."112

In an amicus brief filed two days later, these transgender rights organizations advanced an alternative, statutory argument: the court could avoid the constitutional issue by construing the ADA's transgender exclusion to apply only to GID and not to gender dysphoria - a new and distinct diagnosis with physical roots. ${ }^{113}$

In response to the Notice of Constitutional Question filed by Ms. Blatt pursuant to Rule 5.1 of the Federal Rules of Evidence, the DOJ under Attorney General Loretta Lynch urged the court to avoid

107 Blatt Br. in Opp'n, supra note 102, at 28-34.

108 See id. at 34-39; see also supra notes 71-78 and accompanying text (discussing ADA's legislative history).

109 See Blatt Br. in Opp'n, supra note 102, at 35; see also Romer v. Evans, 517 U.S. 620, 634-35 (1996) (concluding that "a bare ... desire to harm a politically unpopular group cannot constitute a legitimate governmental interest"-much less a compelling or important one) (quoting U.S. Dep't of Agric. v. Moreno, 413 U.S. 528, 534 (1973) (alteration in original)); Barry et al., supra note 84, at 574-77 (discussing transgender exclusion's roots in moral animus).

110 Memorandum from Jennifer Levi, Dir., Transgender Rights Project, Gay \& Lesbian Advocates \& Defs. et al., to Eric Holder, Jr., U.S. Attorney Gen., Dep't of Justice et al. (Jan. 21, 2015) [hereinafter Levi Memorandum] (on file with authors).

111 Id. at 1.

112 Id. at 5.

113 See Brief of Amici Curiae Gay \& Lesbian Advocates \& Defenders et al. in Opposition to Defendant's Partial Motion to Dismiss at 11, Blatt v. Cabela's Retail, Inc., No. 5:14-cv4822-JFL, 2015 WL 1322781 (E.D. Pa. Jan. 23, 2015). 
addressing the constitutionality of the ADA's GID exclusion by first resolving Ms. Blatt's Title VII claims. ${ }^{114}$ When the court determined that the constitutional issue could not be avoided, ${ }^{115}$ DOJ filed a supplemental statement of interest on November 16, 2015 that reached the same result as amici, albeit by slightly different means. ${ }^{116}$ Gender dysphoria is not distinct from GID, DOJ argued, but emerging science indicates that gender dysphoria is a GID that results from a physical impairment (i.e., neurological, genetic, and/or hormonal sources) and, therefore, does not fall within the exclusions. ${ }^{117}$

Over a year and a half later, on May 18, 2017, the court in Blatt denied Cabela's motion to dismiss the ADA claim. ${ }^{118}$ Rather than adopting amici's or DOJ's statutory argument in favor of ADA coverage for gender dysphoria, the court settled on a third interpretation. According to the court, "gender identity disorder," as used in the ADA, refers simply to transgender identity (i.e., "the condition of identifying with a different gender") - not to medical conditions like gender dysphoria that transgender people may have. ${ }^{119}$ The ADA does not protect transgender identity (i.e., gender identity disorder), but it does protect gender dysphoria, which is a serious medical condition.

On July 17, 2017, the U.S. Department of Justice under Attorney General Jeff Sessions filed a statement of interest in a separate case, Doe v. Arrisi, supporting coverage of gender dysphoria under the ADA. ${ }^{120}$ "[B]ecause Plaintiff has alleged that her GD

114 Statement of Interest of the United States of America, Blatt v. Cabela's Retail, Inc., No. 5:14-CV-04822 (E.D. Pa. July. 21, 2015).

115 Order, Blatt v. Cabela's Retail, Inc., No. 5:14-CV-04822 (E.D. Pa. Sept. 21, 2015).

116 Second Statement of Interest of the United States of America, Blatt v. Cabela's Retail, Inc., No. 5:14-CV-04822 (E.D. Pa. Nov. 16, 2015).

$117 I d$. at 5 ("In light of the evolving scientific evidence suggesting that gender dysphoria may have a physical basis, along with the remedial nature of the ADA and the relevant statutory and regulatory provisions directing that the terms 'disability' and 'physical impairment' be read broadly, the [ADA's exclusion of gender identity disorders not resulting from physical impairments] should be construed narrowly such that gender dysphoria falls outside its scope.").

118 Blatt v. Cabela's Retail, Inc., No. 5:14-CV-04822, 2017 WL 2178123, at *4 (E.D. Pa. May 18, 2017). For further discussion of this case, see generally Kevin Barry \& Jennifer Levi, Blatt v. Cabela's Retail, Inc. and a New Path for Transgender Rights, 127 YALE L.J.F. 373, 385 (2017) (discussing Blatt's holding).

119 Blatt, 2017 WL 2178123; see also id. at *3 n.3 (likening "gender identity disorder" to "homosexual[ity] or bisexual[ity]," none of which are medical conditions covered by the ADA).

120 Statement of Interest of the United States of America, Doe v. Arrisi, No. 3:16-cv-08640, at 2-3 (D.N.J. July 17, 2017) [hereinafter Arrisi Stat. of Int. of U.S.]. 
resulted from a "physical impairment,", DOJ stated, "by definition she has alleged that she falls within the statutory protections of the ADA."121 Three months later, DOJ filed a nearly identical statement in yet another case, Doe v. Dzurenda. ${ }^{122}$ Notwithstanding multiple opportunities to reverse course in recent months, DOJ has not done so. Instead, for over three years, and under two separate administrations, DOJ has supported ADA coverage of gender dysphoria as a matter of statutory interpretation.

Significantly, throughout this time, DOJ has never argued that Congress's purported exclusion of gender dysphoria would be constitutional, nor has it articulated a legitimate purpose that could be advanced for its exclusion. ${ }^{123}$ On the contrary, when explicitly invited by courts to defend the constitutionality of the exclusion, DOJ expressly declined to do so. ${ }^{124}$ Tellingly, no defendant has attempted to defend the constitutionality of the ADA's transgender exclusion either. $^{125}$

On December 8, 2017, transgender rights and disability rights advocates and lawyers, including those who identified as both transgender and having a disability, as well as those who identified as neither transgender nor having a disability, met in New York to discuss Blatt's implications. ${ }^{126}$ The discussion was wide-ranging, but three broad themes emerged.

The first was an acknowledgment of the importance of disability rights protection for gender dysphoria. Like Senator Alan Cranston thirty years ago, some participants emphasized the

121 Id. at 3.

122 Statement of Interest of the United States of America, Doe v. Dzurenda, No. 3:16-CV1934, at 3 (D. Conn. Oct. 27, 2017).

123 See supra notes 116-17 and accompanying text (discussing DOJ's intervention in support of ADA coverage of gender dysphoria).

124 Compare, e.g., Order Certifying Constitutional Question to Attorney General of the United States, Doe v. Mass. Dep't of Corr., No. 17-12255, at 1 (D. Mass. Feb. 28, 2018), with Notice by the United States of Decision Not to Intervene to Defend Constitutionality of a Federal Statute, Doe v. Mass., No. 17-12255, at 1 (D. Mass. May 30, 2018).

125 See, e.g., Memorandum of Law in Support of Defendants' Opposition to Plaintiff's Motion For Preliminary Injunction, Doe v. Mass., No. 17-12255, at 18 (D. Mass. Feb. 21, 2018) ("Defendants take no position on the constitutionality of the ADA and defer to the United States Attorney General's position regarding the constitutionality of the federal statute.").

126 All references to discussions at the December 8, 2017 meeting are drawn from a memorandum on file with the authors, dated December 12, 2017, summarizing that meeting. 
importance of equal access to civil rights laws. ${ }^{127}$ It would have been discriminatory for Congress to exclude Tay-Sachs Disease from the ADA out of animus toward Jewish people, or sickle cell anemia out of animus toward African American people. So, too, with gender dysphoria; it was discriminatory for Congress to exclude various medical conditions associated with transgender people based on animus toward them.

Other participants emphasized the importance of disability rights protection for gender dysphoria by noting the overlapping systems of oppression and shared experience of stigma among people with disabilities and transgender people. For example, "ugly" laws once prohibited people with disabilities from participating in public life, while laws criminalizing cross-dressing did the same to transgender people. Both groups have experienced a tragic history of forced medical treatment, such as compulsory sterilization of people with disabilities and the use of conversion therapy on transgender people. People with disabilities continue to experience physically inaccessible restrooms, while discriminatory state bills advance laws that would prohibit transgender women from using women's restrooms and transgender men from using men's restrooms. And both groups have experienced exclusion from service in the military based on treatable medical conditions.

Still others noted the important gaps in antidiscrimination statutes that disability rights law can fill, including protection from discrimination in public accommodations, protection from discrimination in government facilities such as prisons, the requirement that employers provide reasonable accommodations such as medical leave or modified work schedules, and protection from associational discrimination.

Several participants also noted objections raised by nontransgender allies to disability rights coverage for gender dysphoria (e.g., "Why would you want to be protected by the ADA?"), and stated that these objections, while perhaps well-intentioned, reflected paternalism toward transgender people and prejudice toward people with disabilities.

A second theme was a recognition that disability advocacy involves navigating contradictory disability models. For example, in

127 See supra notes 68-70 and accompanying text (discussing Sen. Alan Cranston's objections to Sen. Jesse Helm's amendment to the Fair Housing Amendments Act). 
order to obtain social security disability benefits, a person must advance a stigmatizing "medical model" of disability by arguing that the medical condition, itself, "disables" the person, rendering the person unable to work. Under this model, which reflects the most common understanding of disability, the word "disability" connotes a medical condition that limits bodily functions. By contrast, when invoking the protections of disability antidiscrimination laws like the ADA or Section 504, a person advances a more empowering "social model" of disability by arguing that one is able to work or eligible to receive a service in spite of a medical condition, but is "disabled" by others' prejudicial, stereotypical, or neglectful attitudes and actions. Under the social model, "disability" connotes oppression, not an inability to function. Participants noted that, although some disability laws rely on a stigmatizing definition of "disability" rooted in the medical model, laws like the ADA and Section 504 do not; they are instead premised on the social model and are vital to securing rights for people who experience discrimination based on a medical condition.

One participant captured disability law's contradictory models in the statement of a man living with HIV in the late 1990's, at the time that Bragdon v. Abbott - which established ADA coverage of HIVwas pending before the Supreme Court. ${ }^{128}$ "I have HIV," the man said, "but I'm not disabled." What the man probably meant was that he was capable of working and was therefore not "disabled" for purposes of social security law. But if he, like the plaintiff in Bragdon, were refused services by a dentist based on irrational fears about HIV, the man would have been "disabled"- and therefore protected from discrimination - under the ADA. As with HIV, effective advocacy on behalf of people with gender dysphoria requires a thoughtful understanding of the promise and perils of both models of disability law.

A third theme was a recognition of beneficial collaborations that have already taken place between disability rights and LGBT rights organizations (e.g., HIV/AIDS advocacy and, more recently, transgender autistic advocacy), and a commitment to further collaboration regarding disability rights coverage for gender dysphoria and other matters at the intersection of transgender and disability rights. Notwithstanding perceived differences between disability and

128524 U.S. 624 (1998). 
transgender rights organizations (e.g., "LGBT groups have more money and greater success in the courts"; "Disability groups have bipartisan support and greater success in Congress"), the two groups have much in common, and the communities they serve overlapnamely, transgender people with disabilities, who are among the most marginalized in our society.

\section{The Future Of Disability Rights Protections For Transgender PEOPle}

As a result of the Blatt litigation, transgender litigants have challenged discrimination under the ADA and Section 504 in a broad range of settings. At the time of this writing, there are at least fifteen pending or recently decided cases under the ADA and Section 504 alleging discrimination based on gender dysphoria. As depicted in the figure below, these cases are of three varieties - employment, prisoner rights, and insurance and identity documents - and loosely represent the three primary types of discrimination that people with disabilities typically experience: prejudice, stereotypes, and neglect. ${ }^{129}$

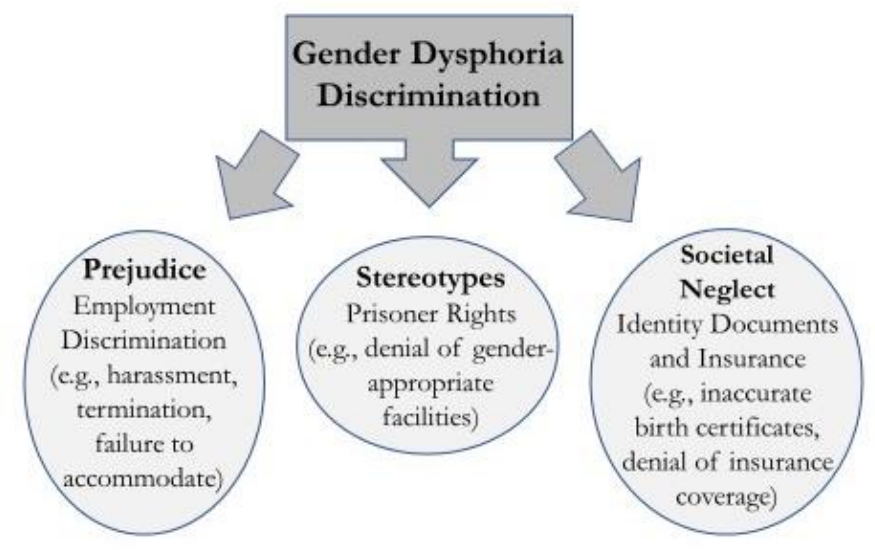

In nearly every case, the defendant(s) invoked the ADA's and/or Section 504's transgender exclusion to dismiss the claim. ${ }^{130}$ A brief

\footnotetext{
129 For illustrative purposes, the following groups of cases are organized around one of the three types of discrimination. In reality, nearly all cases involve all three types of discrimination.

130 Several defendants, including the United States in Doe v. United States, and Wal-Mart in Bost v. Sam's East, Inc., did not invoke the transgender exclusion. See, e.g., Defs.' Br. Supp. Part'l Mot. Dismiss, Bost v. Sam's East, No. 1:17-cv-1148, at 2 (M.D.N.C. Mar. 15, 2018) [hereinafter Defs.' Br., Sam's East]; Fed'l Defs.' Br. Supp. Mot. Dismiss at 1, Doe v. U.S., No. 3:16-cv-0640 (S.D. Ill. Aug. 23, 2016). In fact, in Bost v. Sam's East, Inc., the
} 
description of each case follows, together with noteworthy developments.

\section{A. Employment Discrimination}

The first type of case involves employment discrimination under Title I of the ADA. In the following cases, transgender employees experienced daily insults and indignities on the job after undergoing transition. These cases best illustrate the rank prejudice that transgender people often experience: offensive name-calling, intentional misgendering, denial of gender-appropriate services, and outright exclusion. Because the ADA, unlike other civil rights laws, requires reasonable accommodations in the workplace, the potential impact of the following cases could be significant for employees with gender dysphoria - particularly, those who need to modify their work schedule or take leave to seek counseling, hormone therapy, electrolysis, surgery, or other treatment. ${ }^{131}$

\section{Blatt v. Cabela's Retail, Inc.}

In Blatt v. Cabela's Retail, Inc., Kate Lynn Blatt, a transgender woman, brought suit under the ADA after experiencing daily insults and indignities as a merchandise stocker at a popular sporting goods store. ${ }^{132}$ According to her complaint, coworkers at Cabela's called her "he/she," "fag," "freak," and other humiliating names, and store management refused the very modest accommodations she requested. ${ }^{133}$ Cabela's would not issue her a female uniform or a nametag bearing her female name. ${ }^{134}$ It refused to allow her to use the female employee washroom and required her to use the single-person bathroom at the front of the store-after originally suggesting that she

defendant, Wal-Mart, explicitly conceded that gender dysphoria is not excluded by the ADA. See Defs.' Br., Sam's East, supra, at 2 (distinguishing gender dysphoria from transsexualism and GID).

131 See 42 U.S.C. 12111(9) (2018) (defining "reasonable accommodation" under ADA); see generally U.S. EQUAL EMPLOYMENT OPPORTUNITY COMM'N, ENFORCEMENT GUIDANCE: REASONABLE ACCOMMODATION AND Undue HaRdShIP Under tHE AMERICANS With DisABILITIES ACT (2002), http://www.eeoc.gov/policy/docs/accommodation.html\#leave (discussing types of reasonable accommodations under ADA).

132 First Amended Complaint and Jury Demand TIT 13-36, Blatt v. Cabela's Retail, Inc., No. 5:14-CV-04822 (E.D. Pa. Nov. 5, 2014). Ms. Blatt also sued under Title VII. Id. II 2.

133 Id. III 16-18, 21, 26, 33.

134 Id. IIII 16-18, 32. 
use the bathroom at a Dunkin Donuts across the street. ${ }^{135}$ Cabela's also unfairly disciplined Ms. Blatt and, after just six months on the job, abruptly fired her. ${ }^{136}$

Blatt settled in 2017 after the district court's landmark decision holding that gender dysphoria is protected by the ADA. ${ }^{137}$

\section{Parker v. Strawser Construction, Inc.}

In Parker v. Strawser Construction, Inc., Tracy Parker, a transgender woman who worked as a truck driver, sued her employer for violating the ADA. ${ }^{138}$ Like Ms. Blatt, Ms. Parker experienced relentless taunts from coworkers who mocked her appearance, stating that she "ma[d]e for an ugly woman." ${ }^{139}$ Ms. Parker was also unfairly disciplined, denied access to a gender-appropriate bathroom, repeatedly misgendered (including in her termination letter), and sexually assaulted by coworkers and management who asked her to perform sexual favors. ${ }^{140}$

On April 25, 2017, the U.S. District Court for the Southern District of Ohio dismissed the plaintiff's ADA claim on grounds that "gender dysphoria . . . is expressly excluded from the definition of "disability" under the ADA. ${ }^{141}$ In reaching this result, the court rejected the holding of Blatt, finding "no support" for Blatt's determination that the ADA protects "disabling" GIDs but not "nondisabling" GIDs. ${ }^{142}$ The Parker court's analysis of Blatt is mistaken. ${ }^{143}$

Blatt did not say that some GIDs are "disabling" and protected, and other GIDs are "non-disabling" and excluded, as the Parker court

135 Id. IIII 19, 28-31.

136 Id. IIT 34-36.

137 Blatt v. Cabela's Retail, Inc., No. 5:14-cv-04822, 2017 WL 2178123, at *2-4 (E.D. Pa. 2017); see also supra notes 100-19 and accompanying text (discussing Blatt).

138 First Amended Complaint for Damages Jury Demand Endorsed Herein III 34, 221-34, Parker v. Strawser Construction, Inc., No. 2:17-cv-541 (S.D. Ohio. July 17, 2017). Ms. Parker also sued under Title VII and state law. Id. IIII 11, 13.

139 Id. গII 58-60, 80-82.

140 Id. III 47-169.

141 Parker v. Strawser Construction, Inc., 307 F. Supp. 3d 744, 753-54 (S.D. Ohio 2018) ("Congress intended to exclude from the ADA's protection both disabling and non-disabling gender identity disorders that do not result from a physical impairment.").

142 Id. at 754.

143 For a correct interpretation of the Blatt case, see generally Barry \& Levi, supra note 118 (discussing Blatt's holding); see also supra notes and accompanying text (discussing Blatt). 
suggested. ${ }^{144}$ Rather, Blatt said that gender dysphoria is different than GID: gender dysphoria refers to a medical condition that is protected, and GID - as used in the ADA - refers to transgender identity (not a medical condition) that is excluded. ${ }^{145}$ The Parker court reached the wrong result because it erroneously conflated gender dysphoria and GID; Blatt correctly determined that the two are not the same. Unfortunately, because the plaintiff in Parker did not plead that gender dysphoria results from a physical impairment, the plaintiff's ADA claim could not survive under this alternative argument advanced by DOJ in other cases and adopted by the court in Doe v. Massachusetts Department of Correction (discussed below). ${ }^{146}$

Because the Parker court did not dismiss the plaintiff's federal and state sex discrimination claims, this case remains pending.

\section{EEOC v. Deluxe Financial Services, Inc.}

In EEOC v. Deluxe Financial Services, Inc., the EEOC filed suit against one of the largest check printers in the U.S. for a broad range of discrimination against Britney Austin, a transgender employee. ${ }^{147}$ The defendant refused to permit Ms. Austin to use a gender-appropriate restroom, citing "consideration" of "other employees"; refused to change internal documents to reflect Ms. Austin's correct name and sex designation; intentionally misgendered Ms. Austin; and made repeated, derogatory jokes and comments about Ms. Austin's appearance, including calling her names like "Tarzan" (to tease her about her hairiness and clothes) and openly laughing at her at meetings. ${ }^{148}$

Significantly, EEOC's complaint alleged only sex discrimination. ${ }^{149}$ When the employee, Britney Austin, intervened in the lawsuit, she alleged disability discrimination as well, and also challenged, among other things, her employer's maintenance of an

144 See Parker, 307 F. Supp. 3d at 753.

145 See Blatt, 2017 WL 2178123, at *2, 4 (construing "gender identity disorders" under the ADA "to refer to only the condition of identifying with a different gender," and contrasting this term with the medical condition of "gender dysphoria").

146 See Parker, 307 F. Supp. 3d at 755; see also supra notes 99, 117, 120-22 and infra note 174 and accompanying text.

147 Complaint at 1, EEOC v. Deluxe Fin. Servs., Inc., No. 0:15-cv-02646, 2015 WL 3636151 (D. Minn. June 4, 2015).

148 Id. III 33-73.

149 Id. at 1. 
insurance plan that explicitly excluded all transition-related medical care (including hormone therapy and gender confirmation surgery) for people diagnosed with gender dysphoria. ${ }^{150}$

In January 2016, the case settled, with the defendant agreeing to pay Ms. Austin $\$ 115,000$ and issue her a written apology, eliminating from its insurance plan all exclusions for transition-related medical care, and providing additional antidiscrimination training for employees. ${ }^{151}$

\section{Bost v. Sam's East, Inc.}

In Bost v. Sam's East, Inc., Charlene Bost, a transgender woman who worked at Sam's Club (a subsidiary of Wal-Mart), sued her employer under the ADA after enduring seven years of horrific discrimination after transitioning on the job. ${ }^{152}$ According to her complaint, Ms. Bost regularly experienced derogatory comments (such as being called a "shim," "thing," and "faggot"), deliberate misgendering, unfair discipline, and, ultimately, retaliatory discharge. ${ }^{153}$

Because Ms. Bost did not assert in her complaint that she presently had (or once had) gender dysphoria, her case is the first to allege discrimination based solely on being perceived as having gender dysphoria. ${ }^{154}$ People who transition are typically perceived as having gender dysphoria because transition is the recognized form of medical treatment for gender dysphoria. ${ }^{155}$

Wal-Mart settled the case in June 2018. ${ }^{156}$

150 Complaint in Intervention of Plaintiff/Intervenor Ms. Britney Austin at $1 \&$ III 103-113, EEOC v. Deluxe Fin. Servs., Inc., No. 0:15-cv-02646, 2015 WL 13283300 (D. Minn. Oct. 22, 2015). The plaintiff also brought suit under Title VII. Id. IIII 144-98.

151 Press Release, U.S. Equal Opportunity Emp't Comm'n, Deluxe Financial to Settle Sex Discrimination Suit on Behalf of Transgender Employee (Jan. 21, 2016), https://www.eeoc.gov/eeoc/newsroom/release/1-21-16.cfm.

152 Amended Complaint IIII 2-10, Bost v. Sam's East, Inc., No. 1:17-cv-1148 (M.D.N.C. Apr. 5, 2018) [hereinafter Bost Complaint]. Ms. Bost also brought suit under Title VII of the Civil Rights Act of 1964 and state law. Id. II 1.

153 Id. II 80.

154 Id. III $5,65$.

155 See supra notes 145-47 and accompanying text (discussing transition).

156 TLDEF Announces Settlement in Federal Lawsuit Against Sam's East, Inc., and WalMart Associates, Inc., TRANSGENDER LEGAL DEF. \& EDUC. FUnD, http://transgenderlegal.org/h eadline_show.php?id=945 (last visited Feb. 26, 2019). 


\section{Schawe-Lane v. Amazon}

In Schawe-Lane v. Amazon, a transgender woman, Allegra Schawe-Lane, and her spouse, Dane Lane, a non-transgender man, filed suit after experiencing unrelenting discrimination during their employment at Amazon. ${ }^{157}$ As in Blatt, Parker, and Deluxe, Ms. Schawe-Lane experienced intentional misgendering and a range of epithets, such as "it," "chick with a dick," "shemale," and "tranny prostitute." 158 This humiliating name-calling quickly progressed to intimidation and threats of physical violence. While Ms. Schawe-Lane was using the women's bathroom, a group of women entered. One of the women loudly exclaimed, "It's in here right now," to which another responded, "Maybe we should just drag it outside the fucking stall.". 159 Ms. Schawe-Lane and Mr. Lane experienced similar threats from male co-workers, who yelled that they "should get fucking fired, faggots!" and should "get [their] ass beat." 160 Despite dozens of complaints to Human Resources and, ultimately, the EEOC, the abuse continued, culminating in a horrific incident involving someone tampering with their car in Amazon's secure parking lot. ${ }^{161}$

This case, which is the first to involve a claim of associational discrimination (against Mr. Lane) based on gender dysphoria, is pending.

\section{B. Prisoner Rights}

The second type of case involves discrimination in the prison context under Title II of the ADA and Section 504. In the following cases, transgender people were denied access to proper medical care and gender-appropriate facilities and programs. These cases highlight the pernicious, stereotypical attitudes that people with gender dysphoria often experience: discomfort with people with gender dysphoria, who are often seen as neither male nor female, but rather

157 Complaint and Jury Demand TIII 57-70, Schawe-Lane v. Amazon.com.KYDC LLC, No. 2:17-cv-00134 (E.D. Ky. Aug. 9, 2017) [hereinafter Schawe-Lane Complaint]. The plaintiffs also brought suit under Title VII of the Civil Rights Act of 1964, the Fair Labor Standards Act of 1938, and state law. Id. If 1.

158 Id. $\llbracket 71$.

159 Id. II 77.

160 Id.

161 Id. III 99-109. 
something in between-something less than human, ${ }^{162}$ and fear and distrust of people with gender dysphoria, who are seen as imposters trying to obtain an advantage through deception, iconoclasts trying to undermine community norms, or predators trying to harm others. ${ }^{163}$ Because a disproportionate number of transgender people (one in six, by one study) have been sentenced to prison, ${ }^{164}$ and because sex discrimination statutes do not typically apply in prisons, the potential impact of prisoner rights litigation under the ADA and Section 504 is significant.

\section{Doe v. Massachusetts Department of Correction}

In Doe v. Massachusetts Department of Corrections, the plaintiff, a transgender woman who is currently serving a sentence of three to four years for a non-violent drug offense, sued the Massachusetts Department of Correction and several of its officials for incorrectly housing her in a men's prison in violation of the ADA and Section 504. ${ }^{165}$ As a woman incarcerated in an all-male prison facility, the plaintiff faced serious, daily discrimination and degradation. She was regularly subjected to dehumanizing strip searches by male correctional officers. ${ }^{166}$ She was forced to shower in view of male prisoners who inappropriately commented on her body and otherwise harassed her. ${ }^{167}$ Correctional officers and other staff at the facility refused to address or refer to the plaintiff using her correct name and female pronouns. ${ }^{168}$ And the defendants refused the plaintiff's repeated requests to be transferred to a female corrections facility

162 See Plaintiff Jane Doe's Corrected Motion for Reconsideration of Order on Defendants' Motion for Clarification, Doe v. Mass. Dep't of Corr., No. 1:17-cv-12255, at 4 (D. Mass. Mar. 21, 2018) [hereinafter Pl.'s Mot. for Recon.] (stating that "one of the most pernicious stereotypes about transgender people [is that they are] . . neither male nor female"- they are "less than human[,] . . . an objectified 'it' rather than a person").

163 See supra notes 48-54 and accompanying text (discussing examples of discrimination against people with gender dysphoria).

164 Transgender Incarcerated People in Crisis, LAMBDA LEGAL, https://www.lambdalegal. org/know-your-rights/article/trans-incarcerated-people (last visited Feb. 26, 2019); see also Polices, Jails, Prisons, NAT'L CTR. FOR TRANSGENDER EQUALity, https://transequality.org/issues/police-jails-prisons (last visited Feb. 26, 2019).

165 Complaint III 1-8, Doe v. Mass. Dep't of Corr., No. 17-12255 (D. Mass. Nov. 15, 2017)

[hereinafter Doe v. Mass. Complaint]

166 Id. II 5.

167 Id.

168 Id. II 65. 
based not on an individualized assessment of actual risks, but rather on the apparent discomfort of female inmates and guards. ${ }^{169}$

A group of disability rights, health and mental health law, and transgender rights organizations submitted an amicus brief in support of the plaintiff's right to bring a claim under the ADA and Section 504, marking the first time that disability and transgender rights organizations have formally come together to advance ADA coverage of gender dysphoria. ${ }^{170}$ "Analysis of the legislative history and text of the ADA, as well as Supreme Court decisions interpreting the ADA and its predecessor, Section 504," amici argued, "compels inclusion of people with gender dysphoria, who routinely experience discrimination based on stigma, prejudice, and ignorance."171

On March 5, 2018, in recognition of the daily harms inflicted on the plaintiff, the court granted the plaintiff's motion for preliminary injunction in part, ordering the defendants, where feasible, "to: (1) utilize female corrections officers when conducting strip searches of Doe; (2) to make permanent the arrangement permitting Doe to shower at different times than male inmates; and (3) to station a corrections officer as a privacy guard while Doe showered."172

On June 14, 2018, the court denied the defendants' motion to dismiss. ${ }^{173}$ The court interpreted the ADA's (and Section 504's) transgender exclusion as not applying to gender dysphoria for two reasons: first, because gender dysphoria "may result from physical causes" 174 (the theory originally advanced by DOJ); and, second,

169 See Reply Memorandum in Support of Plaintiff Jane Doe's Motion for Preliminary Injunction, Doe v. Mass. Dep't of Corr., No. 17-12255, at 1-2 (D. Mass. Feb. 26, 2018) (discussing "climate issues" among female inmates and objections from female guards).

170 Brief of Amici Curiae Bazelon Center for Mental Health Law et al., Doe v. Mass. Dep't of Corr., No. 1:17-cv-12255, at vii-ix (D. Mass. Feb. 27, 2018).

171 Id. at 4.

172 Doe v. Mass. Dep't of Corr., No. 17-12255, 2018 WL 2994403 (D. Mass. June 14, 2018) (citing Order, Doe v. Mass. Dep't of Corr., No. 17-12255, at 5 (D. Mass. Mar. 5, 2018)).

$173 I d$. at $* 2$. In addition to the plaintiff's ADA and Section 504 claims, the court allowed the plaintiff's equal protection claim to proceed on grounds that the plaintiff had stated a claim that the DOC's actions were "based on sex" and "therefore subject to heightened judicial scrutiny above the normal "rational basis' test," and were not "substantially related" to "an important governmental interest." Id. at *9-11. The court also allowed the plaintiff's due process claim to proceed on grounds that the plaintiff had stated a claim that she had experienced "an atypical and significant hardship . . . as compared to other inmates in the Massachusetts prison system" without due process. Id. at *11-12.

$174 I d$. at *6 ("While medical research in this area remains in its initial phases, Doe points to recent studies demonstrating that GD diagnoses have a physical etiology, namely hormonal and genetic drivers contributing to the in utero development of dysphoria."). 
because gender dysphoria "is not merely another term for 'gender identity disorder," but is rather a distinct diagnosis with different diagnostic criteria ${ }^{175}$ (the theory originally advanced by amici in Blatt). This is the first time that a court has adopted either theory of coverage of gender dysphoria; the Blatt court reached the same result by different reasoning. ${ }^{176}$

A contrary interpretation, the court concluded, may well violate equal protection. ${ }^{177}$ Invoking the "heightened judicial sensitivity" required for classifications of "discrete and insular minorities," the court suggested that the ADA's transgender exclusion was "constitutionally suspect." 178 According to the court:

The pairing of gender identity disorders with conduct that is criminal or viewed by society as immoral or lewd raises a serious question as to the light in which the drafters of this exclusion viewed transgender persons. ${ }^{179}$

Such an exclusion was particularly concerning, the court added, given the remedial purpose of the ADA, "which is to redress discrimination against individuals with disabilities based on antiquated or prejudicial conceptions of how they came to their station in life."180 In addition to other "firsts," Doe v. Massachusetts Department of

175 Id. ('In contrast to DSM-IV, which had defined 'gender identity disorder' as characterized by a 'strong and persistent cross gender-identification' and a 'persistent discomfort' with one's sex or 'sense of inappropriateness' in a given gender role, the diagnosis of GD in DSM-V requires attendant disabling physical symptoms, in addition to manifestations of clinically significant emotional distress."); see also id. (expressing agreement with plaintiff's argument that "the decision to treat 'Gender Dysphoria' in DSM-V as a freestanding diagnosis is more than a semantic refinement. Rather, it reflects an evolving re-evaluation by the medical community of transgender issues and the recognition that GD involves far more than a person's gender identification."); see also Jane Doe's Opposition to Defendants' Motion to Dismiss, Doe v. Mass. Dep't of Corr., No. 17-12255, at 13-14 (D. Mass. Feb. 2, 2018) ("Unlike the outdated diagnosis of gender identity disorder, the hallmark or presenting feature of Gender Dysphoria is not a person's gender identity. Rather, it is the clinically significant distress, termed dysphoria, that some people experience as a result of the mismatch between a person's gender identity and their assigned sex. Reflecting this distinction, the diagnostic criteria for Gender Dysphoria in the DSM-V are different than those for gender identity disorder.").

176 See supra notes 118-19 and accompanying text (discussing Blatt decision).

177 Mass. Dep't of Corr., 2018 WL 2994403, at *7.

178 Id. (citing footnote 4 of United States v. Carolene Prods. Co., 304 U.S. 144, 152 (1938)).

179 See id. (quoting Justice Harlan's dissenting opinion in Plessy v. Ferguson, 163 U.S. 537, 559 (1896), for the proposition that "the Constitution, properly interpreted, "neither knows nor tolerates classes among citizens"').

180 Id. at $* 8$. 
Correction marks the first time that a court has addressed the constitutionality of the ADA's transgender exclusion.

Having determined that gender dysphoria is not excluded by the ADA and Section 504, the court went on to conclude that the plaintiff had stated a claim for disparate treatment, disparate impact, and failure to accommodate under the ADA and Section 504. "[U]nlike other female inmates, [the plaintiff] was assigned to a men's prison by virtue of her gender assignment at birth and denied access to facilities and programs that would correspond with her gender identification," thereby stating a claim for disparate treatment. ${ }^{181}$ Additionally, "the DOC's biological sex-based assignment policy has a disparate impact on inmates with GD because it injects them into a prison environment that is contrary to a critical aspect of their prescribed treatment (that they be allowed to live as, in Doe's case, a woman)."182 Lastly, "Doe has adequately pled that she has been denied the reasonable accommodation of a transfer to a woman's prison, as well as that she be addressed by prison personnel in a manner consistent with her gender identity." 183

The court concluded its decision with a strong endorsement of the viability of the plaintiff's claims: "As may be apparent from this decision, the court is of the view that Doe may very well prevail on her ADA [and Section 504] . . claims." 184 In September 2018, the DOC transferred the plaintiff to a woman's correctional facility, marking the first time in history that a transgender woman was transferred from a men's facility to a woman's facility. ${ }^{185}$ Significantly, Massachusetts and Connecticut recently enacted laws that require this result. ${ }^{186}$

This case is pending.

\footnotetext{
181 Id.

182 Id.

183 Id.

184 Id. at $* 12$.

185 Michael Levenson, Transgender Inmate Moved to Women's Prison, Boston Globe (Jan. 25, 2019), https://www.bostonglobe.com/metro/2019/01/24/transgender-inmate-movedwomen-prison/Nf2k5Oqa3Ojnh1yH1IwWkL/story.html.

186 See MASS. GEN. LAws $127 \S 32$ A (2018) (“A prisoner of a correctional institution, jail or house of correction that has a gender identity ... that differs from the prisoner's sex assigned at birth, with or without a diagnosis of gender dysphoria or any other physical or mental health diagnosis, shall be," inter alia, "housed in a correctional facility with inmates with the same gender identity."); CONN. GEN. STAT. § 18-81ii (2018) (“An inmate who has a birth certificate, passport or driver's license that reflects his or her gender identity or who can meet established standards for obtaining such a document to confirm the inmate's gender identity shall presumptively be placed in a correctional institution with inmates of the gender consistent with the inmate's gender identity.").
} 


\section{Doe v. Dzurenda}

In Doe v. Dzurenda, the plaintiff, a sixteen-year-old transgender girl who was in the care and custody of Connecticut's Department of Children and Families (DCF), sued the Department for discrimination under the ADA and Section 504. ${ }^{187}$ According to the complaint, DCF placed her in solitary confinement for nearly three months at an adult woman's prison - even though the plaintiff was never charged with or convicted of an adult crime. ${ }^{188}$ DCF eventually transferred the plaintiff to an appropriate facility for juvenile delinquent girls. ${ }^{189}$ Less than one month later, however, after a fight with several other girls, DCF transferred the plaintiff to a high-security facility for juvenile delinquent boys, where she was held in solitary confinement for seven more months. ${ }^{190}$ None of the other girls involved in the fight, all of whom were observed hitting each other and staff, were transferred or placed in solitary confinement. ${ }^{191}$

As a result of her isolation, the plaintiff had no interaction with other youth and no access to age-appropriate mental health, educational, and rehabilitative services provided to other inmates. ${ }^{192}$ In addition, staff members at the facility for delinquent boys routinely referred to the plaintiff using a male pronoun and her male given name, and refused to permit the plaintiff to express herself as a girl by wearing her own clothes, make-up, or a wig. ${ }^{193}$ Although DCF justified its extraordinary confinement of the plaintiff based on her purported dangerousness, DCF did not similarly confine other youth with histories of misbehavior and assaultive conduct. ${ }^{194}$ Indeed, the plaintiff was the only youth that DCF isolated alone in a unit for many months based on dangerousness. ${ }^{195}$

187 Complaint at $1 \&$ II 1, Doe v. Dzurenda, No. 3:16-cv-01934 (D. Conn. Nov. 23, 2016) [hereinafter Dzurenda Complaint]. The plaintiff also brought suit under the Eighth Amendment, Fourteenth Amendment (due process), the Juvenile Justice and Delinquency Prevention Act, and the Prison Rape Elimination Act. Id. II 1.

188 Id. II 1.

189 Id. II 2.

190 Id. III $1,93$.

191 Id. \I 94.

192 Id. III 2,88

193 Id. III 57, 101, 107.

194 Id. III 94, 107.

195 Id. 
At oral argument on September 19, 2017, counsel for the State of Connecticut appeared to concede that gender dysphoria was not excluded by the ADA. ${ }^{196}$ This case is pending.

\section{Edmo v. Idaho Dep't of Correction}

In Edmo v. Idaho Department of Correction, Adree Edmo, an incarcerated transgender woman sued the Idaho Department of Corrections for discrimination in violation of the ADA and Section 504. ${ }^{197}$ Prior to her incarceration, Ms. Edmo, who is Native American, lived as a woman and was recognized by her Tribe as "Two-Spirit," a Native American concept encompassing cross-gender identifying and gender nonconforming individuals. ${ }^{198}$

Approximately three months after her incarceration, Ms. Edmo was diagnosed with gender dysphoria by a doctor retained by the Department. ${ }^{199}$ Notwithstanding this diagnosis, the Department denied her access to appropriate medical treatment, including access to feminizing hormones, evaluation for sex affirming surgery, and being respected as a woman (for example, by having access to women's clothing and commissary items) while incarcerated. ${ }^{200}$ Instead, the Department repeatedly punished Ms. Edmo for expressing her female gender identity, including subjecting her to solitary confinement. ${ }^{201}$ As a result of the Department's failure to adequately treat her gender dysphoria, Ms. Edmo experienced severe symptoms related to this condition, tragically resulting in one suicide attempt and two attempts to self-castrate. $^{202}$ The Department also refused Ms. Edmo's requests to be transferred from her current unit-where she was sexually assaulted two years earlier, and which posed known risks to her safety- to protective custody. ${ }^{203}$

196 See Minute Entry, Doe v. Dzurenda, No. 3:16-cv-01934 (D. Conn. Sept. 19, 2017) (noting oral argument on Defs.' motion to dismiss).

197 Second Amended Complaint IIII 1-8, Edmo v. Idaho Dep't of Corr., No. 1:17-cv-00151 (D. Idaho Sept. 1, 2017), [hereinafter Edmo Complaint]. In addition to her disability discrimination claims, Ms. Edmo brought claims under the 8th Amendment, 14th Amendment (sex discrimination and disability discrimination in violation of equal protection), Affordable Care Act (sex discrimination), and state law. Id. $\llbracket 7$.

198 Id. III $37-38$.

199 Id. II 40

200 See id. 154.

201 Id. IIII 4-5.

202 Id. II 5.

203 Id. III 6, 57. 
On June 7, 2018, the court denied, inter alia, the Department's motion to dismiss Ms. Edmo's ADA claim. ${ }^{204}$ Responding to the Department's invocation of the ADA's transgender exclusion, the court stated simply: “[T]he issue of whether Edmo's diagnosis falls under a specific exclusion of the ADA presents a genuine dispute of material fact in this case. Therefore, Edmo's ADA claim will not be dismissed." 205 Several months later, on December 13, 2018, the court granted Ms. Edmo's motion for preliminary injunction on Eighth Amendment grounds and ordered the Department to provide Ms. Edmo "with adequate medical care, including gender confirmation surgery."206

This case is pending.

\section{Tate v. Wexford Health Services, Inc.}

In Tate v. Wexford Health Services, Inc., the plaintiff, a transgender woman with several medical diagnoses, including gender dysphoria, sued prison officials and the medical provider for the Illinois Department of Corrections for violating the ADA. ${ }^{207}$ Housed in various male correctional facilities, the plaintiff regularly experienced taunts and other harassment from corrections officers and inmates. ${ }^{208}$ Despite being raped and physically and sexually assaulted while incarcerated, the plaintiff was denied protective housing or transfer to housing with other women, and was instead forced to spend many hours in what was effectively solitary confinement. ${ }^{209}$ And, like the plaintiffs in Doe v. Massachusetts Department of Correction, Dzurenda, and Edmo, the plaintiff in Tate was denied access to appropriate treatment for her gender dysphoria, including medical evaluation for sex affirming surgery and equal treatment as a woman, including access to women's clothing and commissary items. ${ }^{210}$

This case is pending.

\footnotetext{
204 Edmo v. Idaho Dep't of Corr., No. 1:17-cv-00151-BLW, 2018 WL 2745898, at *10 (D. Idaho, June 7, 2018).

205 Id. at $* 8$.

206 Edmo v. Idaho Dep't of Corr., No. 1:17-cv-00151-BLW, 2018 WL 6571203, at *19 (D. Idaho Dec. 13, 2018).

207 Plaintiff Carl Tate's Third Amended Complaint IIII 1, 18-27, Tate v. Wexford Health Servs., Inc., No. 3:16-cv-92 (S.D. Ill. June 19, 2018).

208 Id. IIII 19, 30-33.

209 Id. III 24, 29.

210 Id. গIII 35-49, 57-60.
} 


\section{Pro Se Prisoner Cases}

In addition to the above cases, all of which involve plaintiffs represented by counsel, several transgender prisoners have brought ADA challenges pro se. Not surprisingly, the courts in these cases summarily concluded in a single sentence, without any analysis whatsoever, that gender dysphoria was excluded by the ADA. ${ }^{211}$ Unlike Blatt, these decisions contained no analysis of whether the ADA's transgender exclusion applies to the new diagnosis of gender dysphoria, nor whether the exclusion violates equal protection. ${ }^{212}$ Furthermore, the courts that reached these decisions did not have the benefit of a statement of interest filed by DOJ, which concluded that gender dysphoria is not excluded from the ADA, or an amicus brief filed by state and national transgender rights organizations, which argued the same. ${ }^{213}$ For these reasons, the pro se prisoner decisions have little interpretive value.

\section{Insurance and Identity Documents}

The third type of case involves discrimination in the provision of insurance and identity documents under Titles II and III of the ADA and Section 504. In the following cases, transgender people or their family members were provided with insurance plans that excluded coverage of transition-related medical care, and birth certificates that recorded "sex" based solely on the person's original designation, thereby wrongly designating sex for transgender persons. These cases well illustrate the society-wide neglect of transgender people, for whom society's institutions were not designed, and whose health and safety society has systematically ignored. ${ }^{214}$ Because many insurance plans continue to deny coverage for transition-related care, ${ }^{215}$ and

211 See Gulley-Fernandez v. Wis. Dep't of Corr., No. 15-CV-995, 2015 WL 7777997, at *3 (E.D. Wis. Dec. 1, 2015); In re Outman v. Annucci, 19 N.Y.S.3d 678, 684 (Sup. Ct. 2015).

212 See supra notes 94-99, 102-09 and accompanying text (discussing arguments raised in Blatt).

213 See supra notes 113, 116-17 and accompanying text (discussing DOJ statements of interest and amicus briefs supporting coverage of gender dysphoria).

214 See supra Part II (discussing, inter alia, neglect of people with gender dysphoria); see also Feldblum, supra note 35, at 181-82 (discussing neglect of people with disabilities, Jewish people, and LGBT people).

215 NAT'L CTR. FOR TRANSGENDER EQUALITY, THE REPORT OF THE 2015 U.S. TRANSGENDER SURVEY, supra note 51, at 2 (surveying 27,715 transgender people across the nation, and finding that "[o]ne in four (25\%) respondents experienced a problem in the past year with their 
because at least twenty states have laws that preclude many transgender people from securing accurate birth certificates, ${ }^{216}$ the potential impact of these cases is significant.

\section{Doe v. Arrisi}

In Doe v. Arrisi, the plaintiff, a transgender woman, challenged a New Jersey law that required proof of gender confirmation surgery in order to change the sex classification on her birth certificate. ${ }^{217}$ Like many people with gender dysphoria for whom such surgery is unnecessary, contraindicated, or infeasible, the plaintiff transitioned without surgery. ${ }^{218}$ As a result, the sex designation on her birth certificate is inaccurate. ${ }^{219}$ Although she was classified as "male" at birth, she is female, having undergone gender transition. Specifically, she has undergone hormone therapy, which means that she has sex hormones circulating in her body that are comparable to those of a woman who was assigned the female sex at birth, and, as a result of such therapy, she has female secondary sex characteristics comparable to those of non-transgender women. ${ }^{220}$

The consequences of such discrimination, plaintiff argued, are significant. An inaccurate birth certificate discloses to all the world that the person is transgender and accordingly exposes that person to

\footnotetext{
insurance related to being transgender, such as being denied coverage for care related to gender transition or being denied coverage for routine care because they were transgender. . . More than half $(55 \%)$ of those who sought coverage for transition-related surgery in the past year were denied, and $25 \%$ of those who sought coverage for hormones in the past year were denied.").

216 Changing Birth Certificate Sex Designations: State-By-State Guidelines, LAMBDA LEGAL, https://www.lambdalegal.org/know-your-rights/article/trans-changing-birth-certificat e-sex-designations (last updated Sept. 17, 2018) (collecting state statutes regarding changing sex designations on birth certificates).

217 Amended Complaint TIII 4, 15, 41, Doe v. Arrisi, No. 3:16-cv-08640 (D.N.J. Sept. 22, 2017) [hereinafter Arrisi Complaint]. The plaintiff also brought suit under the Fourteenth Amendment (due process, and sex and disability discrimination in violation of equal protection), and Section 504 of the Rehabilitation Act. Id. II 15.

218 Brief of Amici Curiae Bay Area Lawyers for Individual Freedom et al., Doe v. Arrisi, No. 3:16-cv-08640, at 2, 9 (D.N.J. Nov. 21, 2017) [hereinafter Arrisi Amicus Brief]; see also Arrisi Complaint, supra note 217, III 78, 88.

219 Arrisi Amicus Brief, supra note 218, at 11; see also Arrisi Complaint, supra note 217, II 89.

220 Arrisi Amicus Brief, supra note 218, at 11; see also Arrisi Complaint, supra note 217, II 57.
} 
the risk of violence and other adverse treatment. ${ }^{221}$ To avoid such disclosure, some transgender people may seek invasive surgery that is not otherwise medically indicated or may even be contraindicated. ${ }^{222}$ Such discrimination therefore places some individuals in a double bind: transition without surgery and risk violence and other adverse treatment, or undergo invasive medical surgery that one otherwise would not need in order to avoid such risk. ${ }^{223}$

Citing "a lengthy history of societal prejudice and neglect" shared by people with disabilities and transgender people, a group of transgender rights and health organizations filed an amicus brief supporting coverage of gender dysphoria under the ADA and Section 504, generally, as well as the plaintiff's right to amend her birth certificate without undergoing surgery, specifically. ${ }^{224}$ The amicus brief also advanced three separate theories for why the surgery requirement was discriminatory: it was intentionally discriminatory because it denied an accurate birth certificate to a subclass of people with gender dysphoria (disparate treatment); it was discriminatory in effect because it screened out a subclass of people with gender dysphoria from obtaining an accurate birth certificate (disparate impact); and the State of New Jersey failed to reasonably modify the surgery requirement for a subclass of people with gender dysphoria. ${ }^{225}$

221 Arrisi Amicus Brief, supra note 218, at 13-14; see also Arrisi Complaint, supra note 217, III 14, 59-62; see also JAIME GRANT ET AL., InJUSTICE AT EVERy TuRN: A REPORT OF THE NATIONAL TRANSGENDER DiSCRIMINATION SURVEY 138, 154 (2011), https://issuu.com/translib eralprism/docs/ntds_report_full_228_pages ("Legal and bureaucratic barriers to amending transgender people's identity documents marginalize and stigmatize transgender people. . . Whenever people with incongruent identification documents must produce them, they are potentially revealed as transgender, whether to an employer, clerk, police officer, or airport personnel. Each of these 'outings' presents the possibility for disrespect, harassment, discrimination or violence."); accord Adkins v. City of N.Y., 143 F. Supp. 3d 134, 139 (S.D.N.Y. 2015) ("A mismatch between the gender indicated on the [birth certificate] and the gender of the holder calls down discrimination.").

222 Arrisi Amicus Brief, supra note 218, at 13-14; see also Arrisi Complaint, supra note 217, II 82 .

223 Arrisi Amicus Brief, supra note 220, at 14. In recognition of the negative consequences of inaccurate birth certificates for people who do not need or undergo SRS, the American Medical Association has called for the "elimination of any requirement that individuals undergo gender affirmation surgery in order to change their sex designation on birth certificates and supports modernizing state vital statistics statutes to ensure accurate gender markers on birth certificates." AMERICAN MEDICAL AsSOCIATION, CONFORMING BiRTH Certificate Policies to Current Medical Standards for Transgender Patients H65.967 (2014), https://policysearch.amaassn.org/policyfinder/detail/transgender\%20?uri=\%2 FAMADoc\%2FHOD.xml-0-5096.xml.

224 Arrisi Amicus Brief, supra note 218, at 4.

225 Id. at 9-22. 
Citing Justice Thurgood Marshall's partial concurrence in Cleburne, amici argued that New Jersey's surgery requirement represented a "case of what once was a 'natural' and 'self-evident' ordering" coming to be seen as "an artificial and invidious constraint on human potential and freedom. Shifting cultural, political, and social patterns," they argued, had made past practices "inconsistent with fundamental principles upon which American society rests."226

The State of New Jersey asserted that the surgery requirement was necessary to "ensur[e] accuracy in vital records and reduc[e] the likelihood that vital records are used for fraudulent purposes."227 Despite these assertions of necessity, on July 3, 2018, New Jersey Governor Phil Murphy signed legislation removing the requirement. ${ }^{228}$ The previous governor, Governor Chris Christie, twice vetoed the legislation, calling it "beyond the pale.",229

\section{Doe v. United States}

In Doe v. United States, the parents of a transgender boy, one of whom was a colonel in the United States Armed Forces, sued the federal government and its health insurance program on behalf of their son for categorically denying coverage to service members and their families for "[a]ll services and supplies directly or indirectly related to transsexualism or such other conditions as gender dysphoria" in violation of Section 1557 of the Patient Protection and Affordable Care Act ("Section 1557"). ${ }^{230}$ Section 1557 prohibits federally-funded health insurance programs from, among other things, engaging in disability discrimination prohibited by Section 504.231 According to the plaintiffs, the defendants' categorical exclusion violated Section

226 Id. at 2 (quoting City of Cleburne, 473 U.S. 432, 466 (U.S. 1985) (Marshall, J., concurring in part and dissenting in part); see also City of Cleburne v. Cleburne Living Ctr., 473 U.S. 432, 466 (1985) (Marshall, J., concurring in part and dissenting in part) (citing Brown v. Bd. of Educ., which overturned Plessy v. Ferguson's "separate but equal" doctrine).

227 Brief on Behalf of Defendants in Support of their Motion to Dismiss Plaintiff's Amended Complaint in Lieu of Answer, Doe v. Arrisi, No. 3:16-cv-08640, at 1 (D.N.J. Nov. 6, 2017).

228 Alanna Vagianos, New Jersey Gov. Signs Bills Giving Transgender Residents More Rights, HufFINGTON POST (July 4, 2018), https://www.huffingtonpost.com/entry/new-jerseygov-signs-bills-transgender-rights_us_5b3cbee9e4b09e4a8b291569.

229 See Arrisi Complaint, supra note 217, II 91.

230 Complaint IIII 1-12, Doe v. United States, No. 3:16-cv-640 (S.D. Ill. June 14, 2016) [hereinafter Doe v. U.S. Complaint].

231 Section 1557 of the Patient Protection and Affordable Care Act, U.S. DeP'T Health \& HUMAN SERVS., https://www.hhs.gov/civil-rights/for-individuals/section-1557/index.html (last updated Apr. 25, 2018). 
1557 by denying coverage of puberty-blocking medications for the treatment of gender dysphoria while at the same time providing coverage of those same medications for the treatment of other conditions, such as prostate cancer and endometriosis. ${ }^{232}$

Doe v. United States marked the first time that a plaintiff challenged the denial of insurance coverage for the treatment of gender dysphoria as "disability" discrimination under Section 1557. As a result of a 2016 injunction in a case out of the Northern District of Texas, ${ }^{233}$ currently pending before the Fifth Circuit, the viability of challenging transgender discrimination as "sex" discrimination under Section 1557 remains in flux. This case settled in February 2017.

\section{Manning v. McGettigan}

In Manning v. McGettigan, the plaintiff, a transgender man who was employed by the IRS, requested pre-authorization for chest surgery-a common surgery to treat gender dysphoria in transgender persons transitioning from female to male. ${ }^{234}$ Aetna, the federal employee health insurance carrier, denied pre-authorization on grounds that such surgery is an unnecessary, "cosmetic" procedure. ${ }^{235}$ The plaintiff filed a complaint with the Office of Personnel Management, which is responsible for an insurance carrier's denial of benefits, alleging, among other things, discrimination under Section 504. ${ }^{236}$ Specifically, the plaintiff argued that Aetna's exclusion of the procedure for people with gender dysphoria, but not for people with other diagnoses (including for cancer survivors), is discrimination based on disability. ${ }^{237}$ OPM dismissed the complaint, and the plaintiff

232 Doe v. U.S. Complaint, supra note 230, TII 4-7, 84. The plaintiff also alleged sex discrimination and associational discrimination under Section 1557, as well as violations of the Fifth Amendment (due process, and sex and disability discrimination in violation of equal protection). Id. II 12 .

233 On December 31, 2016, in Franciscan Alliance, Inc. v. Burwell, the U.S. District Court for the Northern District of Texas enjoined enforcement of the Department of Health and Human Service's regulation interpreting Section 1557's prohibition on "sex" discrimination to include discrimination based on "gender identity." Section 1557 of the Patient Protection and Affordable Care Act, supra note 231.

234 Plaintiff's Brief in Support of Notice of Appeal at 2, Manning v. OPM, No. 0120161068 (E.E.O.C. Mar. 17, 2016).

235 Id. at 2.

236 Id. at 2 \& n.3.

237 Id. 
appealed the denial to the EEOC. ${ }^{238}$ In response, OPM invoked Section 504's transgender exclusion in support of dismissal of the plaintiff's appeal. 239

On March 6, 2017, the EEOC reversed OPM's dismissal and required OPM to process the plaintiff's claim. ${ }^{240}$ Significantly, the EEOC rejected OPM's argument that gender dysphoria is excluded from the ADA. Instead, in a footnote to the decision, the EEOC determined that an individual who alleges that "gender dysphoria results from a physical impairment . . . states a claim" under the Rehabilitation Act. ${ }^{241}$ The EEOC's determination in Manning is significant, given its decision in 1994, in Bell v. Shalala, dismissing a transgender federal employee's disability discrimination claim based, in part, on Section 504's exclusion of "transsexualism."242

\section{Musgrove v. Board of Regents}

Similarly, in Musgrove v. Board of Regents of the University System of Georgia, the plaintiff, a transgender man who is employed by the University of Georgia, sued the University and its health and disability insurance carriers, Blue Cross Blue Shield and MetLife, for their refusal to cover the costs of his chest surgery and other gender dysphoria-related treatments in violation of the ADA and Section 504. ${ }^{243}$ According to the plaintiff, the defendants' exclusion of coverage of medically necessary and effective medical procedures for the treatment of gender dysphoria, while covering the same procedures for other diagnoses, reflected "the historical stigmatization of his medical condition." ${ }^{244}$ Importantly, Musgrove is the first case to allege discrimination against insurers (under ADA Titles I and III and Section 504), in addition to employers (under ADA Titles I and II and

\footnotetext{
238 Id. at 4.

239 Manning v. McGettigan, E.E.O.C. App. No. 0120161068, at 4-5 n.3 (E.E.O.C. Mar. 6, 2017).

240 Id. at 5.

241 Id. at 4-5 n.3.

242 Bell v. Shalala, E.E.O.C. Appeal No. 01941146, 1994 WL 1755505, at *3 \& n.3 (E.E.O.C. Sept. 9, 1994) (citing EEOC's ADA regulations excluding "transsexualism," 29 C.F.R. $§ 1630.3(d)(1))$.

243 Complaint for Damages III 44-61, Musgrove v. Bd. of Regents of the Univ. Sys. of Ga., No. 3:18-cv-00080 (M.D. Ga. June 28, 2018). The plaintiff also brought suit under Title VII, Title IX, and the Fourteenth Amendment (disability, sex, and transgender status discrimination in violation of equal protection). Id. II 6 .

244 Id. গII $2,44$.
} 
Section 504), for excluding coverage of treatments for gender dysphoria.

\section{Conclusion}

For over a quarter of a century, the ADA and its predecessor, Section 504, excluded transgender people from antidiscrimination protection based on disability. While tearing down one "shameful wall of exclusion" for people with disabilities, these laws erected anotherdenying transgender people the very "opportunity to blend fully and equally into the rich mosaic of the American mainstream" that was promised to others with stigmatized medical conditions. ${ }^{245}$ This Article has examined the shameful history of the ADA's and Section 504's transgender exclusion, the advocacy that led to disability rights protection for gender dysphoria in a range of settings, and the impact these cases will have in redressing the prejudice, stereotypes, and societal neglect experienced by people with gender dysphoria.

245 Remarks of President George Bush at the Signing of the Americans with Disabilities Act, supra note 41. 